UNITED STATES DEPARTMENT OF THE INTERIOR

Harold L. Ickes, Secretary

GEOLOGICAL SURVEY

W. C. Mendenhall, Director

Bulletin 900-C

\title{
SUBSURFACE GEOLOGY \\ AND OIL AND GAS RESOURCES OF OSAGE COUNTY, OKLAHOMA
}

Part 3. Townships 24 and 25 North Ranges 8 and 9 East

BY

N. W. BASS, L. E. KENNEDY, J. N. CONLEY AND J. H. HENGST

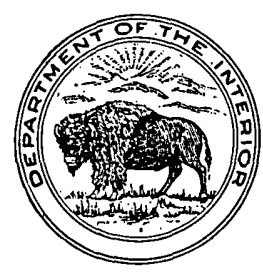

UNITED STATES

GOVERNMENT PRINTING OFFICE

WASHINGTON : 1939

For sale by the Superintendent of Documents, Washington, D. C. - - - . - - Price 40 cents 


\section{FOREWORD}

This report on the subsurface geology of Osage County, Okla., describes the structural features, the character of the oil- and gas-producing beds, and the localities where additional oil and gas may be found. It embodies a part of the results of a subsurface geologic investigation of the Osage Indian Reservation, which coincides in area with Osage County. The investigation was conducted by a field party of the Geological Survey from 1934 to 1937 , and involved the study of the records of about 17,000 wells that have been drilled in Osage County. Funds for the investigation were allotted to the Geological Survey by the Public Works Administration. The primary purpose of the examination was to obtain geologic data for use in the administration of the Indian lands. The results of the inquiry have shown that many localities in Osage County outside the present. producing oil fields are worthy of prospecting for oil and gas and that additional oil and gas can be found also by exploring deeply buried beds in old producing. fields.

All townships in Osage County that contain many wells are described; the information furnished by such townships is ample for drawing detailed subsurface structure-contour maps. The descriptions of several contiguous townships are combined in separate reports, which are issued as parts of a single bulletin. No edition of the consolidated volume will be published, but the several parts can be bound together if desired.

The subsurface investigation of Osage County was carried on mainly by L. E. Kennedy, W. R. Dillard, H. B. Goodrich, C. T. Kirk, J. D. McClure, Otto Leatherock, Constance Leatherock, W. E. Shamblin, J. N. Conley, H. D. Jenkins, J. H. Hengst, G. D. Gibson, and N. W. Bass, geologists. The work of each geologist. contributed more or less to the results of the investigation in each township. However, the investigations of the individual townships in Osage County were made mainly by various individuals of the group, and their names appear in the township descriptions. In addition to those whose names appear above, valuable assistance in the compilation of information was given by Lucile Linton, S. B. Thomas, R. C. Beckstrom, B. A. Lilienborg, J. G. Dwen, K. H. Johnson, J. G. Beaulieu, C. R. Viers, E. L. Hitt, Grace Clark, R. A. Payne, and J. C. Rollins.

Oil companies and individuals who contributed information are too numerous to acknowledge all by name. Special mention is made, however, of LaughlinSimmons \& Co. and the Indian Territory Illuminating Oil Co. for supplying most of the well elevations used in Osage County; of the Continental Oil Co., Tide Water Associated Oil Co., Sinclair Prairie Oil Co., Indian Territory Illuminating Oil Co., Phillips Petroleum Co., W. C. McBride, Inc., The Carter Oil Co., and others for supplying well logs, maps, cuttings, and cores of the producing sands in Osage County.

H. D. Miser, geologist in charge of the section of geology of fuels, under whose direction the investigation was made, supervised the work upon which the report is based. Appreciative acknowledgment is here made of many suggestions made by him during the progress of the investigation and during the preparation of the manuscript. Grateful acknowledgment is due the officers of the Osage Indian Agency at Pawhuska, and the late J. M. Alden, and others in the Tulsa office of the Geological Survey for cooperation and assistance; also H. B. Soyster and H. I. Smith of the Geological Survey for sponsorship and interest in the investigation. 


\section{CONTENTS}

Abstract Page

Introduction.

Oil- and gas-producing rocks

Siliceous lime and Simpson formation

Burgess sand-Mississippi lime zone................ 86

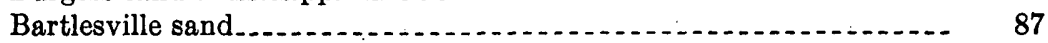

Skinner sand.........

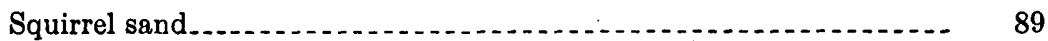

Oswego lime (Fort Scott limestone) ...

Peru sand . . . . . . . . .

Big lime (Oologah limestone) $\ldots \ldots \ldots$

Jones and Cleveland sand zone and Wayside sand............. 90

Layton sand .................................................... 91

Mussellem and Peoples sand zone............................. 91

Okesa, Torpedo, and Clem Creek sand zone................. 91

Revard and Cheshewalla sands............................. 92

T. 24 N., R. 8 E. . . . . . . . . . .

Structure and development................................. 93

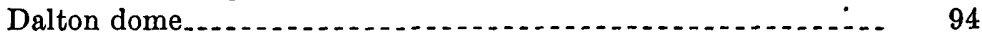

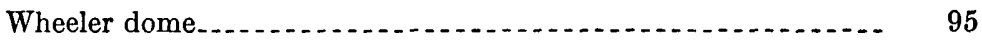

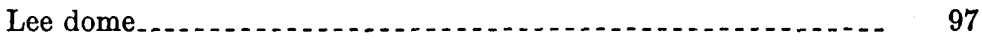

Thirty-six anticline.

Falls anticline.............. 100

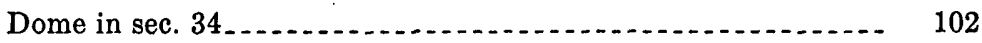

Other domes and anticlines.............................. 102

T. 25 N., R. 8 E. . . . . . .

Structure and development. . . . . . .

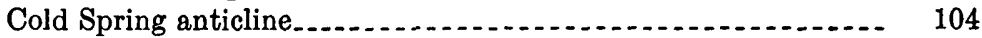

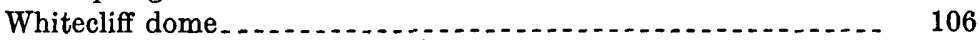

Mayer anticline .........

Rodeo anticline $\ldots 8$

Polledoak dome. 109

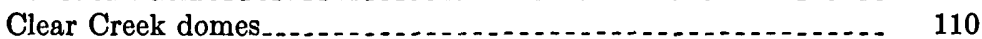

T. 24 N., R. 9 E.

Structure and development.................................. 111

West Birdseye anticline, Fourmile dome, and dome in secs. 23 and 26 (Wynona field) . . . . . . . . . . . . . . . . . . . . . . 112

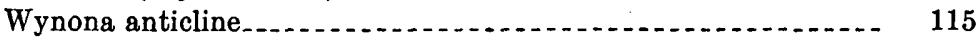

Bandwheel dome....................................... 115

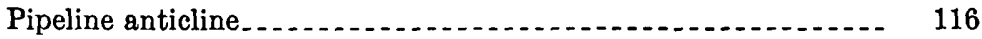

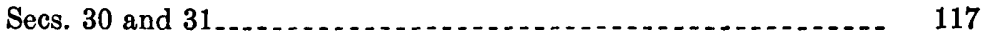

Bulldog anticline............. 118

Postoak anticline and dome in sec. 8 . . . . . . . . . . . . 119

Cottonmouth anticline. . . . . . . 120

Sec. 1... 121 
T. 25 N., R. 9 E. . . . .

Structure and development_.............. 122

Saucy Calf anticline and Pershing field.................. 123

Wooster anticline and north part of Cottonmouth anticline.... 125

Okay anticline............ 125

Mayer anticline _...

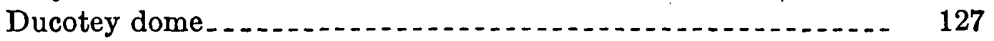

Pawhuska anticline.

Other domes and anticlines. . . . . . . . . . . . . . 129

\section{ILLUSTRATION}

Plate 3. Map of Tps. 24 and 25 N., Rs. 8 and 9 E., Osage County,

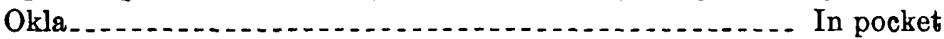




\title{
SUBSURFACE GEOLOGY AND OIL AND GAS RESOURCES OF OSAGE COUNTY, OKLAHOMA
}

\author{
Part 3. Townships 24 and 25 North, Ranges 8 and 9 East
}

\author{
By N. W. Bass, L. E. Kennedy, J. N. Conley, and J. H. Hengst
}

ABSTRACT

The four townships, Tps. 24 and 25 N., Rs. 8 and 9 E., whose subsurface geology and oil and gas resources are described in this report, lie near the center of Osage County, Okla., about 30 miles northwest of Tulsa. Pawhuska, the county seat, and Wynona lie within the area. All but the northwestern part of the area of these four townships contains oil and gas fields. These fields lie along the northwestern margin of a large oil- and gas-bearing region that occupies all of southeastern Osage County. Several fields in this region were discovered more than 25 years ago. About 1,550 wells-oil wells, gas wells, and dry holes-have been drilled in the four townships. Oil or gas has been produced from 17 beds, which lie at depths ranging from about 200 to a little more than 2,900 feet. The oldest oil- or gas-bearing zone is in the Ordovician system, another is in rocks adjacent to the contact of the Mississippian and Pennsylvanian series, and all the others are in the Pennsylvanian series.

The main Ordovician producing beds consist of cherty dolomite in the uppermost 50 feet of the Siliceous lime. The oil in these beds occurs on pronounced upfolds in the southwestern half of the area.

In most localities that produce oil and gas from beds lying near the contact of the Mississippian and Pennsylvanian series the oil occurs in porous chert beds that lie below the contact, and therefore in the upper part of the Mississippi lime. A part of a broad belt trending northwestward across Osage County and containing most of the fields that yield oil from these rocks lies in the northwestern twothirds of the area embraced in Tps. 24 and 25 N., Rs. 8 and 9 E. The northwesternmost part of a large region that produces oil mainly from the Bartlesville sand occupies the southeastern third of the area embraced in Tps. 24 and 25 N., Rs. 8 and 9 E. Beds younger than the Bartlesville sand yield oil and gas in several localities in these four townships.

In Tps. 24 and 25 N., Rs. 8 and 9 E., the rocks dip westward at a low angle as they do in much of the rest of northeastern Oklahoma. Although the regional dip across the four townships is about 30 feet to the mile, it is not uniform but is interrupted by local folds. Domes that are of small areal extent but have relatively steep dips are the most prominent local structural features. Most of them have structural closures of less than 100 feet on the Oswego lime (pl. 3). Most of the folds in the four townships lack any apparent systematic arrangement but when the structure of Osage County is viewed as a whole they and other steeply and gently folded rocks in the County appear to be arranged in poorly 
defined belts. One of these belts extends northeastward from the vicinity of Cushing, Okla., to the vicinity of Pawhuska and includes much of Tps. 24 and 25 N., Rs. 8 and 9 E. The northwestern part of the area enclosed in these townships lies in a belt of country that is essentially devoid of steeply folded domes.

Although the folds in the subsurface rocks conform in general shape and position to the folds in the exposed rocks the crests of domes in the buried rocks are rarely directly beneath the crests of domes in the exposed rocks. Moreover, the structural relief in the buried rocks is greater than that in the exposed rocks. The exposed rocks are cut by many short normal faults, which trend northwestward and are arranged in two narrow belts, one trending northeastward through the western part of T. 24 N., R. 8 E., and the central part of T. 25 N., R. 8 E., ${ }^{1}$ and the other trending through the western and central parts of Tps. 24 and $25 \mathrm{~N}$., R. $9 \mathrm{E}$. The individual faults within these belts are arranged en echelon. The vertical displacement of the exposed beds is rarely more than 50 feet. Although the data appear too meager to determine whether the deeply buried beds are faulted also, the few data available suggest that the faults do not penetrate to great depth.

The investigation has shown that there are a few localities thus far not tested in Tps. 24 and 25 N., Rs. 8 and 9 E., that are prospectively valuable for oil and gas; that several producing oil fields contain areas within and adjacent to them that have not been thoroughly tested; that the practice of treating limy reservoir beds with acid will continue and result in increased yields of oil and gas; and that additional oil will eventually be produced by gas repressuring and by water flooding some of the oil-producing sands.

\section{INTRODUCTION}

The subsurface geologic features, the oil- and gas-producing beds, and the areas that are favorable for the discovery of additional oil and gas in Tps. 24 and 25 N., Rs. 8 and 9 E., Osage County, Okla., are described in this report. The structure of the buried rocks, the oil and gas wells, the abandoned wells and dry holes, and the ownership of leases are shown on the accompanying map (pl. 3). The oil- or gasproducing rocks in producing wells and abandoned producers, and the deepest beds penetrated in dry holes are shown on the map by colors on the well symbols. Wells that produced oil or gas from shallow depths and were drilled deeper to test older beds are indicated by special symbols.

All the oil- and gas-producing rocks in Tps. 24 and 25 N., Rs. 8 and $9 \mathrm{E}$., are described briefly, but the other rocks that have been penetrated are not described. All rocks penetrated by the drill are shown graphically, however, in a generalized columnar section on plate 3. The beds that produce oil or gas are indicated by colors on the columnar section. The colors on the columnar section correspond to the colors on the well symbols on the structure contour map. The names of the oil- and gas-producing rocks in each of the four townships are shown also in the following table.

1 Miser, H. D., Geologic map of Oklahoma, U. S. Geol. Survey, 1926. Fath, A. E., The origin of the faults, anticlines, and buried "granite ridge" of the northern part of the Mid-Continent oil and gas field, U. S. Geol. Survey Prof. P8per 128, pl. 12, 1920. 
Oil- or gas-bearing rocks in Tps. 24 and 25 N., Rs. 8 and 9 E., Osage County, Okla.

\begin{tabular}{|c|c|c|c|}
\hline T. 24 N., R. 8 E. & T. 25 N., R. 8 E. & T. 24 N., R. 9 E. & T. 25 N., R. 9 E. \\
\hline $\begin{array}{l}\text { Cheshewalla sand. } \\
\text { Revard sand. } \\
\text { Okesa, Torpedo, and } \\
\text { Clem Creek sand zone. } \\
\text { Mussellem and Peoples } \\
\text { sand zone. } \\
\text { Jones and Cleveland sand } \\
\text { zone and Wayside sand. } \\
\text { Big lime. } \\
\text { Peru sand. } \\
\text { Oswego lime. } \\
\text { Skinner sand. } \\
\text { Bartlesville sand. } \\
\text { Burgess sand-Mississippi } \\
\text { lime zone. } \\
\text { Simpson formation or } \\
\text { Siliceous lime. }\end{array}$ & $\begin{array}{l}\text { Cheshewalla sand. } \\
\text { Okesa, Torpedo, and } \\
\text { Clem Creek sand zone. } \\
\text { Mussellem and Peoples } \\
\text { sand zone. } \\
\text { Big lime. } \\
\text { Oswego lime. } \\
\text { Skinner sand. } \\
\text { Burgess sand-Mississippi } \\
\text { lime zone. } \\
\text { Simpson formation or } \\
\text { Siliceous lime. }\end{array}$ & $\begin{array}{l}\text { Okesa, Torpedo, and } \\
\text { Clem Creek sand zone. } \\
\text { Layton sand. } \\
\text { Jones and Cleveland sand } \\
\text { zone and Wayside sand. } \\
\text { Big lime. } \\
\text { Peru sand. } \\
\text { Oswego lime. } \\
\text { Skinner sand. } \\
\text { Bartlesville sand. } \\
\text { Burgess sand-Mississippi } \\
\text { lime zone. } \\
\text { Simpson formation or } \\
\text { Siliceous lime. }\end{array}$ & $\begin{array}{l}\text { Layton sand. } \\
\text { Big lime. } \\
\text { Oswego lime. } \\
\text { Squirrel sand. } \\
\text { Bartlesville sand. } \\
\text { Burgess sand-Missis- } \\
\text { sippi lime zone. }\end{array}$ \\
\hline
\end{tabular}

The rocks that are exposed in the townships here described include the Nelagoney, Elgin, Pawhuska, and Buck Creek formations of the Pennsylvanian series. Their distribution is shown on the State geologic map of Oklahoma by Miser, ${ }^{2}$ and their character and attitude were described many years ago by Heald, Mather, and Bowen. ${ }^{3}$ For those areas for which few or no data on the attitude of the buried rocks are available the structure contour maps of the exposed rocks prepared by Heald, Mather, and Bowen were used extensively in drawing the structure contour lines on plate 3 .

\section{OIL- AND GAS-PRODUCING ROCKS}

Oil or gas has been produced in Tps. 24 and 25 N., Rs. 8 and 9 E., from 17 beds ranging from the uppermost part of the Siliceous lime of Ordovician age upward to the Cheshewalla sand in the Nelagoney formation of the Pennsylvanian series. Depths to the oil- or gas-bearing rocks range from 200 feet to 2,950 feet. Wells that produce oil from the Siliceous lime have yielded the largest flows. The Bartlesville sand and the Burgess sand-Mississippi lime zone are important oil-producing zones. The oil- or gas-producing rocks are described briefly from the oldest to the youngest on the following pages.

\section{SILICEOUS IIME AND SIMPSON FORMATION}

Oil in Ordovician rocks has been found at only a few localities in Tps. 24 and 25 N., Rs. 8 and 9 E. The upper part of the Siliceous lime and the overlying Simpson formation of Luther White constitute the Ordovician rocks of this region; the lower part of the Siliceous lime is of probable Cambrian age. The uppermost beds of the Sili-

2 Miser, H. D., Geologic map of Oklahoma, U. S. Geol. Survey, 1926.

8 Heald, K. C. (T. 25 N., R. 9 E.), Heald, K. C., and Mather, K. F. (Tps. 24 and 25 N., R. 8 E.), Heald, K. C., and Bowen, C. F., in White, David, and others, Structure and oil and gas resources of the Osage Reservation, Okla.: U. S. Geol. Survey Bull. 686, pp. 27-41, 149-170, 193-212, 1922. 
ceous lime are finely crystalline brown to white dolomite that commonly contains chert. The Simpson formation consists of medium to coarse, rounded to angular quartz sand and light-green shale. In this part of Osage County the Simpson represents a thin northwardtapering wedge that pinches out along an irregular line passing northwestward through the southern part of T. 25 N., R. 9 E., and the northeastern part of T. 25 N., R. 8 E. ${ }^{4}$ Accordingly, the Simpson formation is absent throughout much of T. $25 \mathrm{~N}$., R. 9 E., and the northeasternmost part of T. $25 \mathrm{~N}$., R. $8 \mathrm{E}$., but attains a thickness of about 50 feet in the southern part of T. 24 N., Rs. 8 and 9 E.

The Siliceous lime as shown by deep wells in Osage County is 1,000 or more feet thick but is very thin or absent on the crests of some sharply folded domes. Abundant evidence in Osage County and elsewhere in northeastern Oklahoma indicates that peaks of preCambrian crystalline rocks underlie many of the sharply folded domes at shallow depths and that Ordovician and Cambrian rocks that are thin or absent on the crests thicken within short distances on the flanks of the domes. Such a relationship appears to be present on the Wheeler dome in secs. 15 and 16, T. 24 N., R. 8 E., where three wells were drilled into granite at depths ranging from 2,480 to 2,708 feet. Granite was encountered also in one well at a depth of 2,830 feet on the dome in the $\mathrm{S} 1 / 2$ sec. 19 , T. 25 N., R. 8 E.

Beds in the uppermost 50 feet, and in most localities only the uppermost 5 to 20 feet, of the Siliceous lime yield most of the oil that is derived from Ordovician rocks. In most localities the oil in these rocks is confined to sharply folded domes. However, the Wheeler dome, in T. 24 N., R. 8 E., which is one of the most prominent domes in the region, is an exception; no oil is found in Ordovician rocks on the crest of this dome, but it is found on the east flank more than 100 feet structurally lower than on the crest. Several prominent domes that have been tested for oil and gas in Ordovician rocks in Tps. 24 and 25 N., Rs. 8 and 9 E., have been found barren. In fact, no oil has been found in these rocks in the northeast half of the area embraced in Tps. 24 and 25 N., Rs. 8 and 9 E., although this area includes several sharply folded domes. As has been pointed out by W. R. Dillard, ${ }^{5}$ it may be significant, or it may be a coincidence, that the area containing no known oil fields in Ordovician rocks is also the area in which the Simpson formation is absent or is only a few feet thick.

\section{BURGESS SAND-MISSISSIPPI LIME ZONE}

Oil is found in many localities in Osage County in rocks that lie at or near the contact of the Mississippi lime and the Cherokee shale.

\footnotetext{
- White, L. H., Subsurface distribution and correlation of the pre-Chattanooga ("Wilcox sand") series of northeastern Oklahoma: Oklahoma Geol. Survey Bull. 40, vol. 1, pl. 2, 1928.

$s$ Oral communication.
} 
Among other localities, oil is produced from these beds in secs. 12, $13,15,16,22$, and 32 , T. 24 N., R. 8 E., secs. $19,23,24,29$ to 31 , T. 25 N., R. 8 E., and secs. 10 and 19, T. 25 N., R. 9 E. The depths to the oil-producing beds in these localities range from about 2,250 to 2,450 feet: Most of the oil pools in these rocks lie in a broad belt that trends northeastward through central Osage County and includes the northwestern two-thirds of the area embraced in Tps. 24 and 25 N., Rs. 8 and 9 E. This belt lies adjacent to the northwestern margin of a large area in southeastern Osage County that produces oil mainly from the Bartlesville sand.

Sand that is composed of fine to coarse, angular to rounded quartz grains forms the basal bed of the Cherokee shale in many localities in southeastern Osage County. It lies on chert beds of the uppermost part of the Mississippi lime or is separated from them by a thin bed of shale. The sand is known as the Burgess sand, but in many wells, beds recorded in the logs as Burgess sand really are chert zones in the underlying Mississippi lime-in drilling, the chert is crushed into fine angular particles that resemble sand grains. Therefore, these rocks at or near the contact of the Cherokee shale and Mississippi lime are referred to herein as the Burgess sand-Mississippi lime zone because

- it is impossible to differentiate them in the drillers' logs. However, it has been determined from microscopic examination of drill samples that in Tps. 24 and 25 N., Rs. 8 and 9 E., the oil-bearing rocks of this zone occur in the Mississippi lime and are composed of chert and locally of chert and limestone. Much of the chert is weathered to a white, porous rock, but some light-gray chert appears to be unweathered and is broken by the drill into sharply angular fragments. The Bartlesville sand along its northwestern margin directly overlies chert beds of the Mississippi lime, as in secs. 27, 28, 33, and 34, T. 25 N., R. 9 E. That the oil in these places occurs in both the Bartlesville sand and the Mississippi lime is indicated by many drillers' logs and by microscopic examination of drill cuttings available from a few wells.

\section{BARTLESVILLE SAND}

The northwestern margin of the important area in Osage County that produces from the Bartlesville sand passes northeastward a short distance southeast of the center of the area embraced in the four townships, Tps. 24 and 25 N., Rs. 8 and 9 E. No Bartlesville sand except patches of local extent is present northwest of this margin. In the - townships here described the most important fields whose oil is derived mainly from the Bartlesville sand are the Pershing field whose northwestern part is in T. 25 N., R. 9 E., and the Wynona field in T. 24 N., R. 9 E. The Bartlesville sand occurs as thick lenses in the lower part of the Cherokee shale. In most localities along its northwestern margin the Bartlesville sand is in contact with the Mississippi

150640-39-2 
lime, but southeast of this margin in the townships here described it is separated from the Mississippi lime by a thin bed of shale. This shale bed thickens southeastward and is 175 to 200 feet thick at the southeast corner of Osage County.

The Bartlesville sand as shown by microscopic examination of well samples is composed mainly of fine and medium subangular quartz grains and minor amounts of other minerals, including mica and feldspar. It is similar in composition and physical character to the Burbank (Red Fork) sand, which occurs somewhat higher in the Cherokee shale than the Bartlesville sand and is an important oil producer in western Osage County, Okla., and in Cowley, Butler, and Greenwood Counties, Kans. The Naval Reserve oil field, which is one of the important fields whose oil is derived from the Burbank sand, lies in Osage County only 3 miles west of the west boundary of T. 24 N., R. 8 E. The Bartlesville sand is similar also to the Bluejacket sandstone member of the Cherokee shale, which crops out in northeastern Oklahoma and southeastern Kansas and which is probably the approximate equivalent of the Bartlesville sand.

The subsurface geologic investigation of Osage County has shown that the Bartlesville sand was laid down as a series of beach deposits on the western shore of the Cherokee sea; ${ }^{6}$ that the oil-bearing sand occurs as lens-shaped bodies that are longer than they are wide; and that the distribution of the lenses of oil-bearing sand is for the most part independent of the attitude of the rocks.

In many places gas occurs in the upper part of the Bartlesville sand and oil occurs at varying positions below the top. Salt water occurs below the oil in many fields; in other fields the sand is practically free from water. It is noteworthy that some of the most productive parts of the Wynona field in the eastern part of T. 24 N., R. 9 E., lie in a syncline between two prominent domes (pl. 3). The oil-producing Bartlesville sand of the Pershing field whose northwestern part lies in T. 25 N., R. 9 E., occupies an area in which the rocks are structurally high, but local domes and synclines appear not to have affected the distribution of the oil in the Bartlesville sand, except to segregate the gas and oil.

The Bartlesville sand characteristically gives up its oil at a slow rate but yields throughout a long time. There are many wells in the Bartlesville sand in northeastern Oklahoma that have produced oil for 20 to 30 years. The first two oil wells in the Wynona field, which were drilled in 1905 and 1906, are still producing. Recently the Bartlesville sand oil pools have received added attention from the oil industry because of the successful operation of gas repressuring and water-flooding projects in a few fields in northeastern Oklahoma.

\footnotetext{
- Bass, N. W., Leatherock, Constance, Dillard, W. R., Kennedy, L. E., Origin and distribution of Bartlesville and Burbank shoestring oil sands in parts of Oklahoma and Kansas: Am. Assoc. Petroleum Geologists Bull., vol. 21, No. 1, pp. 55-56, 1937.
} 


\section{SKINNER SAND}

A thin sand that lies about 100 feet below the top of the Cherokee shale at the general stratigraphic position of the Skinner sand is recorded in relatively few logs in Tps. 24 and $25 \mathrm{~N}$., Rs. 8 and $9 \mathrm{E}$. The well records indicate that the sand is extremely lenticular. It is an important producer only in secs. 6 and 7, T. 24 N., R. 8 E., where it has produced oil in seven wells at depths of about 2,340 feet. It has yielded small amounts of oil in a few other localities, including the Cold Spring anticline in T. 25 N., R. 8 E.

\section{SQUIRREL SAND}

Local lenses of sand, called the Squirrel, occur in the upper part of the Cherokee shale between the Verdigris lime and the Oswego lime. The lower boundary of the sand lies at various stratigraphic horizonsin some localities the Squirrel sand occupies the position of the Verdigris lime. The Squirrel sand ranges from a feather edge to 100 feet in thickness and occurs mainly in a belt that trends northeastward through the northwestern part of T. 25 N., R. 9 E. Shale occurs at the position of the sand in many localities elsewhere. The sand yields oil and gas in the northwestern part of T. 25 N., R. 9 E.; it is the principal gas-bearing bed in the vicinity of Pawhuska.

\section{OSWEGO LIME (FORT SCOTT LIMESTONE)}

The Oswego lime is one of the most persistent rock units in northeastern Oklahoma. It has long served as one of the most important key beds in subsurface geologic mapping. In Tps. 24 and $25 \mathrm{~N}$., Rs. 8 and $9 \mathrm{E}$., the Oswego lime is recorded in the logs as limestone 50 to 75 feet thick, and commonly includes in the lower part from one to two shale beds 5 to 10 feet thick. Locally, the uppermost 10 to 25 feet of the unit is recorded as oil- or gas-bearing sand, which is called the Wheeler sand by some operators; elsewhere, the oil- and gas-bearing part is porous limestone. The Oswego lime produces gas or oil in several localities in Tps. 24 and 25 N., Rs. 8 and $9 \mathrm{E}$., some of which are the Thirty-six and Falls anticlines and the Wheeler dome in T. 24 N., R. 8 E., and the Cottonmouth anticline in Tps. 24 and 25 N., R. 9 E. The oil- and gas-bearing beds of the Oswego lime have responded with increased yields after acid treatment in many localities in Osage County.

\section{PERU SAND}

Sand occurs locally in the upper part of the Labette shale at the position of the Peru sand of northeastern Osage County. The main occurrences of the sand in Tps. 24 and 25 N., Rs. 8 and 9 E., are in a narrow belt that trends northeastward from sec. 36, T. $24 \mathrm{~N}$., R. 8 E., through secs. $31,30,20,17$, and 3, T. 24 N., R. 9 E., and 
secs. $33,34,27,14$, and 1 , T. 25 N., R. 9 E. In this belt the sand ranges from a few feet to 75 feet in thickness and yields oil or gas in a few wells in sec. 36 , T. 24 N., R. 8 E., in two wells in sec. 20 , and several wells in sec. 3 , T. 24 N., R. 9 E. It is recorded also in the logs of many wells in a rather poorly defined belt through secs. 5 and 6 , T. 24 N., R. 8 E., secs. 29 and 3, T. 25 N., R. 8 E., and is recorded in the logs of many wells in the $\mathrm{SE} 1 / 4$ sec. 13 , and the eastern parts of secs. 24,25 , and 36 , T. 24 N., R. 9 E.

\section{BIG LIME (OOLOGAH IIMESTONE)}

The Big lime is a persistent limestone unit about 75 feet thick in Tps. 24 and 25 N., Rs. 8 and 9 E. In some localities it is split into three members by a shale bed near the middle. The shale bed contains a sandstone in a few localities, which yields oil in a few wells in T. 24 N., R. 8 E. The sandstone lies at the stratigraphic position of the Weiser sand (also called Hancock sand) of northeastern Osage County. The Big lime yields oil or gas in commercial quantities in only a few wells in Tps. 24 and 25 N., Rs. 8 and 9 E., but yields shows of oil and gas in many wells. It is possible that in a few localities shows of oil and gas in the Big lime will be converted into profitable amounts by treatment of the reservoir beds with acid.

\section{JONES AND CLEVELAND SAND ZONE AND WAYSIDE SAND}

Shale, lenticular beds of sandstone and local limestone lentils occupy an interval of about 160 feet that lies between the Big lime below and the Checkerboard limestone member of the Coffeyville formation above. These rocks occupy the positions of the Nowata shale, Lenapah limestone, and the lower part of the Coffeyville formation of northeastern Oklahoma. Two or three beds of limestone, each of which ranges from 5 to 20 feet in thickness, are recorded in the logs of many wells in a zone about 75 feet thick near the middle of the unit. Some of these limestone beds lie in the stratigraphic position of the Lenapah limestone, but certain identification of the Lenapah cannot be made in the logs. The beds of sandstone occur mainly in two units, one above and the other below the limestone zone. Locally, however, the upper sandstone occupies the position of the limestone lentils. The lower sandstone appears to occupy about the stratigraphic position of the Wayside sand, which occurs beneath the Lenapah limestone in northeastern Oklahoma. The sand is also at the position of the lower part of the Cleveland sand of the Cleveland oil field, which is in the northernmost part of Pawnee County. There the Lenapah limestone appears to be absent, and the Cleveland sand locally occupies much of the interval between the Big lime and the Checkerboard limestone; therefore the Cleveland may be equivalent to the Nowata shale, the Lenapah limestone, and the lower part 
of the Coffeyville formation. In the Cleveland field the upper bench of the Cleveland sand is called also the Jones sand.

The upper of the two sands in Tps. 24 and 25 N., Rs. 8 and 9 E., is tentatively designated herein the Jones and Cleveland sand zone, and the lower sand is designated the Wayside sand, although both sands are commonly called Cleveland by the drillers. Oil is produced from the Jones and Cleveland sand zone in several wells in secs. 25 and 26, T. 24 N., R. 9 E., and from the Wayside sand in sec. 32, T. 24 N., R. 9 E.

\section{LAYTON SAND}

The term "Layton" is applied to all sands in the upper part of the Coffeyville formation. The individual beds are lenticular, but the logs of most wells in Tps. 24 and 25 N., Rs. 8 and 9 E., record sand at this general stratigraphic horizon. The Layton sand is readily identified by its position a short distance below the Hogshooter limestone. The sand yields shows of oil and gas in several localities and produces gas in one well in sec. 17, T. 25 N., R. 9 E., and oil in one well in sec. 25 , T. 24 N., R. 9 E.

\section{MUSSELLEM AND PEOPLES SAND ZONE}

A sequence of sandstone, shale, and limestone about 250 feet thick overlies the Hogshooter limestone. These rocks occupy the positions of the Nellie Bly formation, the Dewey limestone, and the lowermost part of the Ochelata formation of northeastern Osage County and include rocks which are equivalent to the Peoples and Mussellem oil and gas sands. In northeastern Osage County the Dewey limestone lies between the Mussellem and Peoples sands, but in Tps. 24 and 25 N., Rs. 8 and 9 E., several limestone beds, none of .which are persistent, are recorded intermittently through a vertical interval of 100 feet or more. Therefore, it appears impossible to correlate these strata bed for bed, as recorded in the logs. The entire sequence of sands and the included sandy shale, shale, and limestone is referred to here as the Mussellem and Peoples sand zone. Sands in the lower part of the zone are referred to as the Peoples and those in the upper part as the Mussellem. Shows of oil and gas are recorded from these rocks in several wells, and gas has been produced from them in a few wells.

\section{OKESA, TORPEDO, AND CLEM CREEK SAND ZONE}

A sequence of sandstone, limestone, and shale about 175 feet thick lies about 150 feet below the top of the Ochelata formation. The sequence includes rocks that are believed to be equivalent to the Clem Creek, Torpedo, and Okesa sands, each of which produces oil or gas in Osage County. Individual beds in the sequence cannot be identified 
in the logs from well to well but the sequence, considered as a unit, persists through an extensive area. The logs indicate that the sandstones particularly, and the limestones to a lesser extent, are extremely lenticular. The sequence contains a larger proportion of limestone in Tps. 24 and 25 N., Rs. 8 and 9 E., than in many areas in Osage County. Microscopic examination of well samples from a few wells indicate that the sands are composed of fine to very fine angular to subangular, clean quartz grains and contain a trace of mica. Sands in the upper part of the sequence that are tentatively identified as approximately equivalent to the Okesa sand are important producers of oil and gas on the Falls anticline in T. 24 N., R. 8 E.; sands in the lower part of the sequence, which are tentatively identified as the Clem Creek sand, yield oil and gas on the Cold Spring anticline in T. 25 N., R. 8 E. A few wells in other parts of Tps. 24 and $25 \mathrm{~N}$., Rs. 8 and 9 E., yield oil or gas, and many wells yield shows of oil or gas from this sequence of beds.

\section{REVARD AND CHESHEWALLA SANDS}

The lower half of the Nelagoney formation is composed of sandstone, shale, red rock, and a few thin lenticular limestones. Individual beds cannot be identified in the logs from well to well, and even the base of the Nelagoney formation is not closely defined in most logs. In eastern Osage County the lower half of the Nelagoney formation contains, from the base upward, the Bigheart, Revard, and Cheshewalla sands. Accordingly in Tps. 24 and 25 N., Rs. 8 and 9 E., oil or gas sands in the lower part of the Nelagoney formation are tentatively designated the Bigheart, Revard, or Cheshewalla according to their relative positions above the base of the formation. The main producing area for these sands is in secs. 15 and 16, T. 24 N., R. 8 E., on the Wheeler dome.

\section{T. 24 N., R. 8 E.}

T. 24 N., R. 8 E., is a short distance south of the center of Osage County and 4 miles southwest of Pawhuska, the county seat. It contains several oil fields. Eleven oil- and gas-producing zones have been found in T. 24 N., R. 8 E. Of these, lenticular sands in the Ochelata formation and the lower part of the Nelagoney formation are of interest because they yield oil and gas in many wells at depths of only 600 feet. The Oswego line at depths of about 1,800 feet; and the Bartlesville sand at depths of about 2,150 feet, each yield oil or gas in many wells. The Burgess sand-Mississippi lime zone yields small amounts of oil or gas in widely separated localities, and Ordovician rocks yield relatively large amounts in a few localities. Several other beds yield oil or gas in a few wells. 
The subsurface investigation of T. 24 N., R. 8 E., was made in 1935 mainly by J. N. Conley but in part by L. E. Kennedy and N. W. Bass. The production data were compiled in 1938 by Miss Anna L. Weinrich, of the Osage Indian Agency, from records on file at the Agency.

About 400 wells have been drilled in T. 24 N., R. 8 E.; many of them were drilled 20 years or more ago. Most of the wells in secs. 35 and 36 , on the southeastern part of the Thirty-six anticline, were drilled from 1916 to 1918; many of the wells on the northwestern part and the northeastern flank of the anticline were drilled in 1919 and 1920, although many of the Bartlesville sand producers in secs. 25 and 24 were not drilled until 1923 to 1926 . Most of the wells on the Falls anticline in secs. 32 and 33 were drilled between 1921 and 1924. Many of the wells in secs. 15 and 16, on the Wheeler dome, were drilled from 1924 to 1928 , although a few were drilled in 1919 and 1920. Several wells in the NE1/4 sec. 15 were drilled in 1929 and 1930, and most of the wells in sec. 14 were drilled in 1935 and 1936. Most of the wells on the Lee dome in secs. 12 and 13 were drilled in 1926 and 1927; most of those on the Dalton dome in secs. 5, 6, and 7 were drilled in 1926.

\section{STRUCTURE AND DEVELOPMENT}

The regional dip of the rocks in T. 24 N., R. 8 E., is westward at an average rate of 33 feet to the mile. However, many local folds of considerable structural relief almost obscure the regional dip. The most prominent of the local folds are the Thirty-six and Falls anticlines and the Lee, Wheeler, and Dalton domes. These anticlines and domes lie in a belt of country characterized by steeply folded domes and anticlines that extends from the Cushing oil field in western Creek County northeastward to the vicinity of Pawhuska, in central Osage County. Crystalline rocks of the basement complex lie at shallow depth (about 2,500 feet) beneath many of the domes and anticlines in this belt of folded rocks. Many prolific oil and gas fields are associated with the folds.

The structure of the buried rocks in T. 24 N., R. 8 E., closely parallels that of the exposed rocks. ${ }^{7}$ The most notable exception is that of the Dalton dome, whose crest on the Oswego lime (pl. 3) is about three-quarters of a mile west of its position on the exposed rocks. ${ }^{8}$ Furthermore, throughout the township, the buried rocks are more steeply folded than the exposed rocks. The exposed rocks are cut by several normal faults that trend northwestward and that are arranged en echelon in a narrow belt extending north-northeast across the western half of T. 24 N., R. 8 E. ${ }^{9}$ The maximum vertical

\footnotetext{
' Heald, K. C., and Mather, K. F., in White, David, and others, Structure and oil and gas resources of the Osage Reservation, Okla.: U. S. Geol. Survey Bull. 686, pl. 25, 1922.

8 Idem.

- Idem.
} 
displacement of the exposed rocks is only 35 feet. ${ }^{10}$ The data were insufficient to determine whether the deeply buried rocks also are displaced along the faults.

Oil and gas have been produced on each of the principal domes and anticlines in the township. It is noteworthy that oil and gas in the Ordovician rocks and for the most part in the Oswego lime and the shallow sands, including the Okesa and Revard sands, are confined to the higher parts of the folds. It is noteworthy also, that oil in the Bartlesville sand occurs low on the northeast flank of the Thirty-six anticline as well as on the crest of the northwestern part of the anticline. Oil occurs in the Skinner sand low on the southwest flank of the Dalton dome. The occurrence of oil and gas in the Bartlesville and Skinner sands, and probably in several other sands as well, is believed to bear little or no relation to the local attitude of the rocks, although the segregation of the gas from the oil within the sand body of each oil field appears to be controlled by the local structure of the rocks.

\section{DALTON DOME}

The Dalton dome in secs. 5,6 , and 7 is a pronounced upfold that has proved disappointing as an oil and gas reservoir. Of 22 wells drilled on the dome only 6 wells are now producing oil and one is producing gas; a few others produced for a time. Ten wells tested the Siliceous lime at a depth of about 2,850 feet; of these, 6 produced a small amount of oil from beds that lie 15 to 20 feet below the top of the lime, but all have been abandoned. So far as known the oil-bearing beds were not treated with acid in any of the wells. Wells 1 and 3 in the $\mathrm{SE} 1 / 4$ sec. 6 , on or near the crest of the dome, after producing oil for a few years from the Siliceous lime, were plugged back to a depth of about 2,565 feet and produced oil for a time from a zone in the Mississippi lime about 75 feet below its top. Several logs record shows of gas with a maximum volume of $2,500,000$ cubic feet in chert beds near the top of the Mississippi lime and above the position of the oil-bearing bed.

Seven wells that are low on the southwest flank of the Dalton dome yield oil from the Skinner sand at a depth of 2,340 feet. The oilbearing sand is only 15 to 20 feet thick and has produced oil through a structural range of 60 feet. The logs of most of the wells in secs. 5 and 6 record shale at the position of the Skinner sand. Wells 2 and 4 in the NW/4 sec. 7 yielded initially 75 and 90 barrels a day, respectively; the initial yields of the other wells producing from the Skinner sand, except well 1 in the northwest corner of the $\mathrm{NE} 1 / 4$ sec. 7, ranged from 30 to 50 barrels a day. Although the producing history of the

${ }^{10}$ Heald, K. C., and Mather, K. F., op. cit. 
wells is not known, their distribution suggests that additional wells should be drilled west of wells 4 and 5 in the NW/1/4 sec. 7 .

Several wells on the Dalton dome had shows of gas in the Layton sand at depths of about 1,600 feet, in the Okesa, Torpedo, and Clem Creek sand zone in the Ochelata formation at depths of about 1,100 feet, and in other sands at depths of about 700 feet.

Well 444 in the $\mathrm{SE}_{1}^{1} / 4$ sec. 6 was drilled recently to a depth of 1,113 feet, where it yielded 1,600,000 cubic feet of gas from sand, probably the Torpedo, near the middle of the Okesa, Torpedo, and Clem Creek sand zone.

\section{WHEELER DOME}

One of the most sharply folded domes in central Osage County, shown on plate 3 as the Wheeler dome, occupies the central part of T. 24 N., R. 8 E. The structural relief on the Oswego lime is a little more than 100 feet, which is about four times the relief shown by Heald and Mather ${ }^{11}$ on the exposed rocks. Only 1 gas well had been drilled on the Wheeler dome at the time Heald and Mather made their field investigation; now nearly 50 oil or gas wells and several dry holes have been drilled on the dome, and oil or gas has been found in four zones-Ordovician rocks, the Burgess sand-Mississippi lime zone, the Oswego lime, and the Revard sand. Three wells on or near the crest of the dome have been drilled into granite, which was encountered at a depth of 2,480 feet in well 2 and at a depth of 2,708 feet in well 3 in the NE1/4 sec. 16, and at a depth of 2,505 feet in well 41-296 in the NW1/4 sec. 15 . Well 2 in the $\mathrm{NE}^{1} / 4$ sec. 16 is particularly interesting because, according to Mr. Frank Pinney, who drilled the well, oil was found in sand after granite had been penetrated 25 feet; water was found deeper in the sand, below which the drill reentered granite.

Oil is found in the uppermost beds of the Siliceous lime in the NE1/4 sec. 15 , where the deeply buried rocks are more than 100 feet lower structurally than on the crest of the dome. Three wells producing from the Siliceous lime in the $\mathrm{NE}_{1} / 4$ sec. 15 were drilled in 1929 , the first one being completed in July. The three wells had produced a total of 90,603 barrels of oil by the end of 1929. A total of 231,473 barrels had been produced from the Siliceous lime by Nov. 30, 1937, at which time only one well (No. 3) was producing. Well 3 is the only well on the lease in which the oil reservoir rocks have been treated with acid. In the NE/4 sec. 16, where wells 2 and 3 entered granite at shallow depths, the logs indicate that the Ordovician rocks; which are oil-bearing in sec. 15, have been eroded from the crest of the dome.

11 Heald, K. O., and Mather, K. F., op. cit. pl. 25.

$150640-39-3$ 
The Burgess sand-Mississippi lime zone yields oil in several wells that are low on the southeast flank of the dome, also in two wells near the center of sec. 14 on a subsidiary dome on the east flank, and in two wells low on the west flank. Both gas and oil are produced from this zone in well 3 in the $\mathrm{NE}^{1} / 4 \mathrm{sec}$. 22 low on the southeast flank of the dome. The oil and gas occur in beds of chert in the uppermost part of the Mississippi lime, according to the logs and an examination of samples from one well. The distribution of the producing wells suggests that it is reasonable to expect additional oil from these beds at a depth of about 2,350 feet throughout a large area on the southwest and southeast flanks of the dome, but the daily yields of the wells will probably be small.

The 13 wells in the $\mathrm{SE} 1 / 4$ sec. 15 and the $\mathrm{N} 1 / 2$ sec. 22 that produce oil from the Burgess sand-Mississippi lime zone had yielded a total of 274,579 barrels from April 1928 to Nov. 30, 1937. If 10 acres is assumed to be the drainage area for each well, the total yield to the acre had been 2,112 barrels. The average daily yield per well during the first 11 months in 1937 was 8.1 barrels. The lone producer in the northeast corner of the SW $1 \frac{1}{4} \mathrm{sec} .16$, which was completed in July 1920 , had produced 48,528 barrels by Nov. 30,1937 , and the abandoned producer that offsets it on the north produced 9,600 barrels from July 1920 to November 1930. A total of 22,922 barrels had been produced from the $\mathrm{SE} / 4 \mathrm{sec}$. 16. It is likely that most of this oil came from the well in the northwest corner of the lease producing from the Mississippi lime, but the exact amount is not known.

Six wells on the Wheeler dome produced gàs at daily rates of $2,000,000$ to $12,000,000$ cubic feet from the Oswego lime at a depth of about 1,900 feet; the logs of many other wells, including several in the $\mathrm{NE}^{1 / 4}$ sec. 15, record shows of gas, and a few record shows of oil in the Oswego lime. Wells 2 and 3 in the $\mathrm{NE}^{1 / 4}$ sec. 16 had estimated volumes of $6,000,000$ and $2,000,000$ cubic feet but were not saved as gas wells. A considerable volume of gas probably could be developed in the Oswego lime in secs. 15 and 16 by the drilling of additional wells and treatment of the gas-bearing rocks with acid.

A bed in the lower part of the Nelagoney formation, which is tentatively identified as the Revard sand, yields oil in many wells in secs. 16 and 15 on the crest and east flank of the Wheeler dome. The sand is about 30 feet thick, lies at a depth of about 500 feet, and yielded initially from 5 to 100 barrels of oil a day in 19 wells. A total of 22,847 barrels of oil was produced from this sand in the $\mathrm{NE}_{1 / 4} \mathrm{sec} .16$ from 1924 to August 1937, and twice that amount of oil was produced from the NW114 sec. 15, where most of the wells produce from the Revard sand. It is not unlikely, however, that about half of the oil produced from the NW1/4 sec. 15 came from Ordovician rocks in well 14. 
Several beds other than those described above yielded shows of oil and gas, although mainly gas, in many wells on the dome; these beds include the Big lime, the Layton sand, and several sands in the Ochelata and Nelagoney formations.

\section{LEE DOME}

The Lee dome whose crest is in the NW $1 \frac{1}{4}$ sec. 13 occupies an area of less than 1 square mile. Its structural relief on the Oswego lime (pl. 3) is slightly more than 60 feet and on the exposed rocks exceeds 10 feet $^{12}$ by a small amount. Moreover, the dome is not only small but lies in a broad area that is structurally low; its crest is from 50 to 60 feet lower than the crests of the Wheeler dome, and the Thirty-six anticline a few miles to the west and south and is more than 100 feet lower than the crest of the Postoak dome a few miles to the northeast. Nevertheless, the Lee dome yields oil or gas from three zones-the Oswego lime, Burgess sand-Mississippi lime zone, and Ordovician rocks.

Well 346 on the east flank of the dome yielded initially $6,400,000$ cubic feet of gas a day from the Oswego lime at a depth of 1,940 feet. Well 397 in the northwest corner of the $\mathrm{NE} / 4$ sec. 13 yielded initially $17,000,000$ cubic feet of gas a day from the Burgess sand-Mississippi lime zone at a depth of 2,305 feet; two wells that are about a quarter of a mile west and northwest of this gas well yielded less than 25 barrels of oil a day from these beds. Two oil wells that lie a short distance east of the crest of the dome yielded initially 80 and 150 barrels a day from the uppermost beds in the Siliceous lime, the identification of which was established by microscopic study of samples by geologists with The Texas Co. ${ }^{13}$

The distribution of the producing wells on the dome suggests that additional wells with small yields could be found in the Burgess sandMississippi lime zone in the NW1/4 sec. 13 and the SW1/4 sec. 12, and in Ordovician rocks in the $\mathrm{NE}_{1}^{1} / 4 \mathrm{NW}_{1 / 4}$ sec. 13. Particular attention should be given to shows of oil and gas in the Oswego lime. It is possible that large shows in the Oswego lime could be made profitable by treatment of the lime with acid.

The two oil wells in the NE $1 / 4$ sec. 13 produced 31,102 barrels of oil from May 1926 to Dec. 31, 1937, according to records on file at the Osage Indian Agency. The abandoned oil well in the $\mathrm{SE} 1 / 4 \mathrm{sec} .12$ produced 1,367 barrels before it was abandoned in 1926. A total of 34,828 barrels was produced by well 1 in the NW $1 / 4$ sec. 13 and well 1 in the SW1/4 sec. 12 from May 1931 to Nov. 30, 1937. Of this amount the well in sec. 12 produced 19,758 barrels. Moreover, 40 percent of

\footnotetext{
12 Heald, K.C., and Mather K. F., in White, David, and others, Structure and oil and gas resources of the Osage Reservation, Okla.: U. S. Geol. Survey Bull. 686, pl. 25, 1922.

${ }^{13}$ Lukert, L. H., oral communication.
} 
this well's total yield came during the last 18 months after the reservoir rocks had been treated with acid.

In 1934, one well in the southwest corner of sec. 13 and one in the northwest corner of sec. 24, low on the southwest flank of the Lee dome, found oil in the Bartlesville sand. The northern one of the two wells yielded initially 40 barrels of oil a day from a bed of sand 35 feet thick and had yielded a total of 22,910 barrels on Nov. 30 , 1937. The southern one of the two had produced only 5,146 barrels by Nov. 30, 1937. Well 2 in the SW1/4NW1/4NE1/4 sec. 13 found a show of oil, estimated at 20 barrels, in the Bartlesville sand. The logs of other wells on the Lee dome record only a thin bed of sand or shale at the position of the Bartlesville. However, these facts indicate that most of the SW $1 / 4$ sec. 13 and a part of sec. 14 is prospectively valuable for oil in the Bartlesville sand at a depth of about 2,200 feet. Inasmuch as the occurrence of oil in the Bartlesville sand appears not to be controlled primarily by the attitude of the rocks, the fact that throughout much of this area the beds are structurally low does not materially detract from the prospective value for oil in this sand.

\section{THIRTY-SIX ANTICLINE}

The largest anticline in T. 24 N., R. 8 E., occupies much of the southeastern quarter of the township and is called the Thirty-six anticline. ${ }^{14}$ The anticline has a structural closure of 120 feet on the Oswego lime (pl. 3) and of less than half that amount on the exposed rocks. ${ }^{15}$

Oil or gas has been found here in nine zones. Of 179 wells in $\mathrm{T}$. 24 N., R. 8 E., on the anticline, 137 produced oil, 16 produced gas, and 26 were dry. Of 10 wells that tested Ordovician rocks at depths of about 2,450 feet, 1 well (No. 2 in the NE1/4 sec. 35) produced oil. Sixty-two wells yielded oil and 9 yielded gas from the Bartlesville sand at depths of about 2,100 to 2,200 feet. The oil wells yielded initially from 10 to 220 barrels a day and the gas wells from 2,000,000 to $17,000,000$ cubic feet. The Oswego lime yielded oil in 41 wells and shows of oil or gas in many wells in several localities widely distributed over the anticline. The producing bed in the Oswego lime, which is called the Wheeler sand by some operators, is recorded as sand in some wells and as limestone in other wells. The initial daily yields of the Oswego lime oil wells ranged from 15 to 500 barrels. The Peru sand, which lies in the Labette shale between the Oswego lime and the Big lime, yielded oil in 6 wells in the NE/4 sec. 36 . The initial daily yields of the Peru sand oil wells ranged from 15 to 150 barrels.

Seven oil wells on the northwestern part of the anticline yielded initially from 100 to 400 barrels a day from sand near the middle of the Big lime. The producing bed lies about at the position of the

"Heald, K. C., and Mather, K. F., op. cit. pl. 25.

${ }^{16}$ Idem. 
Weiser sand (also called Hancock sand) of northeastern Osage County. Several other wells yielded shows of oil or gas in this bed. Several wells found shows of oil and gas in two or more beds of the Jones and Cleveland sand zone and the Wayside sand that lie between the Big lime below and the Checkerboard limestone member of the Coffeyville above. Well 1 in the center of the west line of the SE1/4 sec. 36 yielded $6,000,000$ cubic feet of gas a day from sand that lies in the Mussellem and Peoples sand zone. Other wells found shows of gas and oil in sand in this zone.

Twelve wells in the southeastern part and one well near the northwest end of the anticline produced oil at a depth of about 460 feet from a thin sand near the top of the Okesa, Torpedo, and Clem Creek sand zone. The oil-producing bed here has been called locally the Osage sand but is tentatively designated herein the Okesa sand because it lies near the top of the zone. The Okesa sand oil wells yielded initially from 10 to 50 barrels a day. Well 439 in the NW/1/4W $\mathrm{SW} / 4$ sec. 36 was drilled in search of water for a nearby pump station but yielded initially 750,000 cubic feet of gas a day from sand at a depth of 205 feet. Many other wells yielded shows of gas from this bed and from beds closely associated with it. This sand lies in the Nelagoney formation near the position of the Cheshewalla sand, but its designation as the Cheshewalla is speculative.

The odd distribution of the producing wells on the Thirty-six anticline indicates that many additional wells could be drilled. For example, several large tracts are nearly surrounded by wells producing from the Bartlesville sand, and other tracts lie adjacent to producing wells. It therefore appears reasonable to conclude that additional wells should be drilled on these tracts, which include the $\mathrm{NE}_{1} / 4$ and $\mathrm{SE} 1 / 4$ sec. $27, \mathrm{SE} 1 / 4$ sec. $22, \mathrm{~S} 1 / 2$ sec. $23, \mathrm{~N} 1 / 2$ sec. 26 , and the $\mathrm{W} 1 / 2$ and $\mathrm{NE} / 4$ sec. 25. The two oil wells in the southwest corner of sec. 13 and the northwest corner of sec. 24 suggest that the large area producing from the Bartlesville sand on the northeast flank of the Thirtysix anticline might be extended northward through the $\mathrm{E} / 2$ sec. 23 and the W $\frac{1}{2}$ sec. 24 and possibly beyond these tracts. The fact that the rocks are structurally low here should not necessarily be considered unfavorable for oil in the Bartlesville sand because in much of southeastern Osage County the occurrence of oil in this sand is controlled by the distribution of the sand lenses rather than by the attitude of the beds. The structure of the rocks in the NW1/4 and $\mathrm{SE} / 4 \mathrm{SE} / 4$ sec. 26 is favorable for the occurrence of oil in Ordovician rocks.

The patchy distribution of tracts producing from the Oswego lime indicates that additional wells should be drilled to this bed in the localities that lie between the producing tracts. It is probable that acid treatment of the oil-bearing beds in the Oswego lime will increase 
the daily yields of the wells. Acid treatment should be given the oilbearing beds in the Big lime in a few wells to determine whether such treatment would increase the yield. Shows of gas recorded in the logs of many wells indicate that it is probable that considerable gas can be obtained from the Bartlesville sand, Jones and Cleveland sand zone, the Mussellem and Peoples sand zone, the Okesa, Torpedo, and Clem Creek sand zone, and also from sands at shallow depths in the Nelagoney formation.

The total amounts of oil produced from the tracts on the Thirtysix anticline, compiled from records at the Osage Indian Agency, are shown in the following table:

Oil produced from the Thirty-sit anticline

\begin{tabular}{|c|c|c|}
\hline Tract & Date of first production & $\begin{array}{l}\text { Production } \\
\text { to end of } 1937\end{array}$ \\
\hline 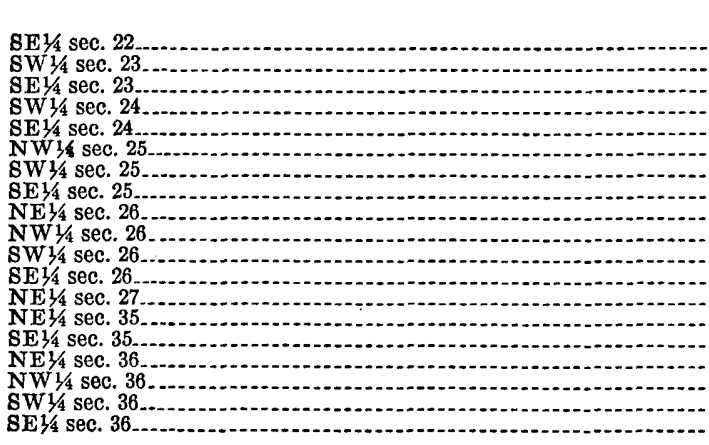 & \begin{tabular}{|l|} 
July 1920 \\
January 1922 \\
July 1929 \\
March 1921 \\
July 1920 \\
January 1921. \\
July 1920 \\
do
\end{tabular} & $\begin{array}{r}\text { Barrels } \\
124,583 \\
168,703 \\
1267,239 \\
205,352 \\
41,235 \\
660,014 \\
137,146 \\
18,445 \\
1217,355 \\
1145,654 \\
1109,938 \\
115,316 \\
1144,168 \\
125,589 \\
11,228 \\
152,258 \\
1152,310 \\
195,625 \\
20,523\end{array}$ \\
\hline & & $2,702,681$ \\
\hline
\end{tabular}

1 To Nov. 30, 1937.

1 Abandoned Aug. 14, 1922.

FALLS ANTICLINE

The Falls anticline in the southwestern part of T. 24 N., R. 8 E., is a prominent structural feature in the exposed rocks ${ }^{16}$ and also in the buried rocks (pl. 3). A deep structural basin lies immediately southeast of the anticline. Eighty-one wells have been drilled on the Falls anticline, and oil has been produced from five beds subsequent to the time Heald and Mather ${ }^{17}$ made their report on the structure of the exposed rocks when the fold was still untested. Most of the wells found oil at a depth of about 700 feet in a thin sand in the upper part of the Ochelata formation. The producing bed lies in the general stratigraphic position of the Okesa sand, although it is referred to locally as the Buzzard sand. The initial yields of the wells ranged from 5 to 60 barrels a day. Three wells that produced initially only from 5 to 15 barrels a day found oil in the Mussellem and Peoples sand

\footnotetext{
10 Heald, K. C., and Mather, K. F., in White, David, and others, Structure and oil and gas resources of the Osage Reservation, Okla.: U. S. Geol. Survey Bull. 686, pl. 25, 1922.

17 Idem.
} 
zone at depths of 1,170 to 1,200 feet. The logs indicate that the oil occurs in the upper part of the zone, which is in the position of the Mussellem sand. Four wells found small amounts of oil in the Oswego lime, and the yields of these wells have been increased recently by treatment of the oil-bearing rock with acid. Several wells on the anticline yielded oil at rates of less than 100 barrels a day from the Burgess sand-Mississippi lime zone at depths of 2,300 to 2,400 feet. This oil-bearing rock is recorded in the logs as chert 30 feet below the top of the Mississippi lime.

A few wells on the north part of the anticline found oil in Ordovician rocks at a depth of about 2,600 feet. . Cuttings from the wells were not studied to determine whether the producing bed is in the uppermost part of the Siliceous lime or in the lowermost part of the Simpson formation. The large volume of oil found in Ordovician rocks is demonstrated by comparisons of the total yields of the leases on the Falls anticline. More oil has been produced from the SE1/4 sec. 29, where three wells produce from Ordovician rocks, than has been produced from any other lease in the field, although two of the leases contain 20 wells each.

Shows of gas in many wells and shows of oil in a few wells were recorded in the Bartlesville, Skinner, and Squirrel sands, the Oswego lime and Big lime, the Layton sand and the Okesa, Torpedo, and Clem Creek sand zone. It is possible that gas could be produced profitably from some of these beds. The shows of oil in the Oswego lime particularly, and in the Big lime in at least a few wells, might be increased to commercially valuable amounts by acid treatment. More wells can probably be drilled to the Mississippi lime, but small yields should be expected. Additional wells should be drilled to the Siliceous lime in the $W 1 / 2 \mathrm{SW}^{1 / 4}$ sec. 28 and in the $\mathrm{NE} 1 / 4$ sec. 32 near the crest of the anticline. Acid treatment of the Siliceous lime beds should result in increased yields.

The total amounts of oil produced on the Falls anticline are given in the following table:

Oil produced on the Falls anticline

\begin{tabular}{|c|c|c|}
\hline Tract & $\begin{array}{l}\text { Date of first } \\
\text { production }\end{array}$ & $\begin{array}{l}\text { Production } \\
\text { to end of 1937 } \\
\text { (barrels) }\end{array}$ \\
\hline \multirow[t]{2}{*}{$\begin{array}{l}\text { SW1/4 sec. } 28 \\
\text { SE1/4 sec. } 29 \\
\text { NEL1/4 sec. } 32 \\
\text { SE1/4 sec. } 32 \\
\text { NW1/4 sec. } 33 \\
\text { SW1/4 sec. } 33\end{array}$} & \multirow[t]{2}{*}{$\begin{array}{l}\text { June 1921 } \\
\text { July } 1922 . \\
\text { March 1922 } \\
\text { July } 1920 \\
\text { April } 1921 \\
\text { August } 1922 \\
\end{array}$} & $\begin{array}{r}118,205 \\
266,709 \\
2260,177 \\
202,144 \\
2179,357 \\
76,748\end{array}$ \\
\hline & & $1,003,340$ \\
\hline
\end{tabular}

1 To September 1935 ; the record since 1935 is unavailable. Of the total of 18,205 barrels, 16,000 barrels was produced in 1935 from well $1-A$.

To Nov. 30, 1937. 


\section{DOME IN SEC. 34}

Heald and Mather ${ }^{18}$ called attention to structural features of the exposed rocks in the $\mathrm{SE} 1 / 4$ sec. 34 that might indicate the presence of oil and gas. From 1928 to 1930 , several years after the publication of their report, several wells were drilled in sec. 34 ; five of these found oil in Ordovician rocks at depths of about 2,600 feet and one well produced oil from the Burgess sand-Mississippi lime zone at a depth of 2,250 feet. The Mississippi lime well yielded initially 20 barrels a day, and the Siliceous lime wells yielded from 40 to 840 barrels a day. Well 442, which was drilled recently, yielded initially $3,000,000$ cubic feet of gas a day from the Okesa sand. The data furnished by the logs show that the fold in sec. 34 is much more pronounced in the buried rocks than in the exposed rocks. The dome and the oilproducing area extend southward into sec. 3, T. 23 N., R. 8 E. The drillers' logs indicate that the main oil-bearing bed is in the uppermost part of the Siliceous lime. The oil-bearing bed in the Burgess sand-Mississippi lime zone lies from 25 to 50 feet below the top of the Mississippi lime. Most of the Ordovician producers had shows of oil or gas in the Mississippi lime, and the log of one well recorded a volume of $3,500,000$ cubic feet of gas from it. Several wells on the dome also had shows of oil or gas in the Bartlesville sand, Oswego lime, Big lime, Mussellem and Peoples sand zone and the Okesa, Torpedo, and Clem Creek sand zone, and a few had shows of gas in beds that lie at shallow depths in the Nelagoney formation.

It is noteworthy that wells 1 and 4 in the $\mathrm{SE} 1 / 4$ sec. 34 on the east flank of the dome yielded initially 500 and 840 barrels of oil a day, and well 5 on the crest of the dome yielded only 40 barrels. Several years ago, the oil-bearing beds in two deep wells in the SE 14 sec. 34 were treated with 500 gallons of acid, but the treatment failed to increase the yields. On Oct. 31,1937 , a total of 421,870 barrels of oil had been produced from the $\mathrm{SE}_{1 / 4}^{1 / 4}$ sec. 34 .

\section{OTHER DOMES AND ANTICLINES}

The small dome shown on plate 3 in sec. 4 has been tested by two wells, each of which entered Ordovician rocks. The well in the SW $1 / 4$ sec. 4, which was drilled in 1934, had a show of 25 barrels of oil a day from the Simpson formation and found water in the Siliceous lime. The log of the well in the $\mathrm{SE}_{14}^{1 / 4}$ sec. 4, which was drilled in 1936, records no shows of oil or gas in the Ordovician rocks.

The Turkey anticline in secs. 17 to 20 has been tested by several wells that reached the Siliceous lime. The anticline lies in an area where the rocks are structurally low. Nevertheless, the two deep

18 Heald, K. C., and Mather, K. F., op. cit., p. 169. 
wells in the $\mathrm{E} 1 / 2$ sec. 18 and the well in the $\mathrm{NE} 1 / 4$ sèc. 19 had shows of oil in.Ordovician rocks.

The Ordovician producer in the southwest corner of the NW1/4 sec. 30 is on the northeast flank of a large dome that lies mainly in the southeastern part of T. 24 N., R. 7 E. The well in sec. 30 yielded initially only 40 barrels a day from sand that is reported in the log to be in the Simpson formation. The well began producing oil in 1925 and by the end of 1937 had produced 21,767 barrels.

$$
\text { T. } 25 \text { N., R. } 8 \text { E. }
$$

T. 25 N., R. 8 E., is in central Osage County. Its eastern boundary is $1 \frac{11}{2}$ miles west of Pawhuska, the county seat. The township lies on the northwest margin of a prolific oil- and gas-bearing region in northeastern Oklahoma, which includes all of southeastern Osage County. It lies a short distance outside of the area containing Bartlesville sand, ${ }^{19}$ which is the principal oil- and gas-bearing bed in this region, but lies in a belt of country that borders the Bartlesville sand-bearing region on the northwest and contains many oil fields that derive oil mainly from the Burgess sand-Mississippi lime zone.

Oil or gas in commercially valuable amounts has been found in half a dozen localities and in eight zones in T. 25 N., R. 8 E. The Burgess sand-Mississippi lime zone produces oil in more than half of the wells; it lies at depths of about 2,350 feet in the eastern part and 2,450 feet in the western part of the township. The largest daily yields have been made from wells that obtain their oil from the Siliceous lime.

A few of the 235 wells in T. 25 N., R. 8 E., were drilled prior to 1919. Most of the wells in secs. 23 and 24 on the Mayer anticline were drilled from 1920 to 1922 . Most of the wells on the east dome of the Cold Spring anticline were drilled from 1920 to 1925 and those on the west domes from 1925 to 1929 , although several wells in the W11/2 sec. 30 on the west flank of the anticline were drilled in 1936 and 1937. Most of the wells on the Whitecliff dome were drilled from 1920 to 1924 ; a few were drilled in 1927 and 1928. Several wells were drilled on the Rodeo anticline and Polledoak dome from 1919 to 1924; others were drilled in 1928 and 1929.

The subsurface investigation of T. 25 N., R. 8 E., was made in 1935 mainly by J. H. Hengst, but partly by L. E. Kennedy. The statistics of oil production were compiled in 1938 by Anna L. Weinrich, of the Osage Indian Agency.

\footnotetext{
10 Bass, N. W., Kennedy, L. E., Dillard, W. R., and Leatherock, Constance, Subsurface geology of Osage County, Okla.: United States Department of the Interior Press Memorandum 105368, pls. 1 and 3, B, 1936.
}

$150640-39-4$ 


\section{-STRUCTURE AND DEVELOPMENT}

T. 25 N., R. 8 E., lies in the western part of a narrow northeastward trending belt of country that is characterized by sharply folded domes. The northwestern part of the township is outside of the folded belt and lies in the easternmost part of a broad area in western Osage County that is essentially devoid of pronounced folds. The Oswego lime, which lies at a depth of about 2,000 feet, has a regional westward dip across the township of about 30 feet to the mile. The most pronounced upfolds in' T. 25 N., R. 8 E., are the Whitecliff dome, Cold Spring anticline, Mayer anticline, the Polledoak dome, and Rodeo anticline. Oil or oil and gas have been found on each of these upfolds. All the main folds in the buried rocks (pl. 3) are present in the exposed rock. The buried rocks are more steeply folded than the exposed rocks, and the crests of the folds in the buried rocks lie a short distance west, southwest, or northwest of the crests on the exposed rocks. In addition the exposed rocks are cut by several northwestward-trending faults, which lie en echelon in a narrow belt that trends northeastward through the middle of the township. The maximum vertical displacement of the exposed rocks is only 40 feet; ${ }^{20}$ the data are insufficient to determine whether the deeply buried rocks are also displaced along the faults.

\section{COLD SPRING ANTICLINE}

A large complex anticline occupies parts of several sections in the southwestern part of the township. It was named the Cold Spring anticline by Heald and Mather ${ }^{21}$ who described it as the most favorable undrilled area for prospecting of all untested anticlines in Tps. 24 and 25 N., R. 8 E. Subsequently 131 producing oil or gas wells were drilled on the anticline, and all possibilities for producing wells are not yet exhausted.

Oil or gas is produced here from the Siliceous lime, the Burgess sandMississippi lime zone, the Skinner sand, Oswego lime, Big lime, Mussellem sand, Clem Creek sand, and Cheshewalla sand. The Burgess sand-Mississippi lime zone produces oil in more than two-thirds of the wells, in which it lies at depths of about 2,400 feet. The oil from this zone ranges in gravity from $39^{\circ}$ to $41^{\circ}$, Baumé. ${ }^{22}$ Several producers in this zone yielded initially from 200 to 400 barrels a day, and many yielded from 50 to 150 barrels. Many of the wells that had large initial yields were found in the $W 1 / 2 \mathrm{~W} / 2 \mathrm{SE} / 4$ and the $\mathrm{SW} / 1 / 4$ sec. 30 and $N \frac{1}{2}$ sec. 31. Several leases whose oil is derived from this zone had yielded between 7,000 and 8,000 barrels to the acre by the end of 1937 .

\footnotetext{
${ }^{20}$ Heald, K. C., and Mather, K. F., in White, David, and others, Structure and oil and gas resources of the Osage Reservation, Okla.: U. S. Geol. Survey Bull. 686, pl. 24, 1922.

${ }^{21}$ Heald, K. C., and Mather, K. F., op. cit., pp. 159-160.

28 Stephenson, O. D., An oil field in T. 25 N., R. 8 E., Osage County, Okla.: Am. Assoc. Petroleum Geologists, Structure of typical American oil fields, vol. 2, p. 392, 1929.
} 
Oil has been found in this zone through a structural range of a little more than 100 feet. Most of the highest part of the east dome is not oil productive in the Burgess sand-Mississippi lime zone, and only a small amount of oil has been found on the subsidiary dome in sec. 19. Development has not been completed, however, and it is probable that other wells will be drilled to extend the producing area southward in sec. 31 , westward in the $W 1 / 2$ sec. 30 , and northward in the $\mathrm{N} 1 / 2$ sec. $2 \dot{9}$.

Several wells on or near the crest of the east dome and three wells on the dome in sec. 19 have produced oil from the uppermost few feet of the Siliceous lime at depths of about 2,650 feet on the east dome and 2,725 feet on the dome in sec. 19. The oil-bearing beds consist of finely crystalline cherty dolomite and underlie a thin bed of green shale and sandy shale of the Simpson formation. Stephenson ${ }^{23}$ pointed out that on the east dome salt water was encountered in sand in the Tyner formation only 5 feet above the oil-bearing bed in the Siliceous lime. The initial yields of the wells are reported to have been from a few barrels to 6,000 barrels a day. All the large producers are on the east dome. Most of the producing area on the east dome is in the NE $1 / 4$ sec. 29 , which tract had produced $1,823,224$ barrels of oil by Nov. 30, 1937. More than three-fourths of this total came from the Siliceous lime. The oil-producing rocks have been acidized in well 1 in the NW1/4 sec. 19 , in well 5 in the SW1/4 sec. 19 , and in well 8 in the $\mathrm{NE}_{1}^{1} / 4$ sec. 29 . The large yields obtained from the Siliceous lime on the east dome would appear to warrant testing this lime on the subsidiary dome on the anticline in the SW $1 / 4$ sec. 30 and probably on the subsidiary dome in the $\mathrm{N} 1 / 2$ sec. 30 . Well 9 in the center of the west line of the $\mathrm{NE}_{1 / 4}^{1 / \mathrm{SW}} 1 / 4$ sec. 19 , near the crest of the dome there, encountered granite at a depth of 2,830 feet, 67 feet below the top of the Siliceous lime.

Five wells in widely separated localities on the Cold Spring anticline produced oil at small daily rates from the Skinner sand at a depth of about 2,300 feet. Three of these wells were later deepened to the Burgess sand-Mississippi lime zone. The logs of most wells in the field, however, recorded no sand at the position of the Skinner sand. The total yield of oil from the Skinner sand from this field probably will not be large.

Several wells on the flanks of the east dome and a few wells in other parts of the Cold Spring anticline found commercial amounts of oil or gas in sand at a depth of about 1,100 feet. The sand lies near the base of the Okesa, Torpedo, and Clem Creek sand zone. The oil- and gas-bearing bed here is tentatively called the Clem Creek sand, mainly because it lies near the base of the zone. The producing sand underlies a limestone about 30 feet thick that is persistent in this

${ }^{23}$ Stephenson, C. D., op. cit., p. 390. 
township. Most of the oil wells producing from the Clem Creek sand yielded initially less than 50 barrels a day; a few yielded from 50 to 75 barrels a day. The gas wells yielded from $2,000,000$ to $5,500,000$ cubic feet a day. Many of the deep wells in this field had shows of gas and oil in the Clem Creek sand; it is probable, therefore, that additional small gas producers could be found in this sand.

Wells 392 and 37-292 in the $\mathrm{NE}^{1 / 4}$ sec. 29 near the crest of the east dome yielded initially 4,000,000 and 7,000,000 cubic feet of gas a day, respectively, from a thin sand in the Nelagoney formation. The sand lies in the general stratigraphic position of the Cheshewalla sand, but its identification as the Cheshewalla is little more than a guess. One of the wells was recently deepened to the Big lime and after receiving acid treatment yielded 1,200,000 cubic feet of gas a day. The other well was deepened to the Burgess sand-Mississippi lime zone and yielded 8,000,000 cubic feet a day. Two wells in sec. 30 near the crest of the west dome yielded gas from the Big lime at depths of about 1,900 feet. Inasmuch as many wells had shows of oil and gas in this bed, it is possible that commercially valuable wells might be developed by acid treatment.

The total amounts of oil produced on the Cold Spring anticline; compiled from records at the Osage Indian Agency are shown in the following table:

Oil produced from the Cold Spring anticline

\begin{tabular}{|c|c|c|}
\hline Tract & Date of first production & $\begin{array}{c}\text { Production } \\
\text { to Nov. 30, } \\
1937 \text { (barrels) }\end{array}$ \\
\hline \multirow[t]{2}{*}{ 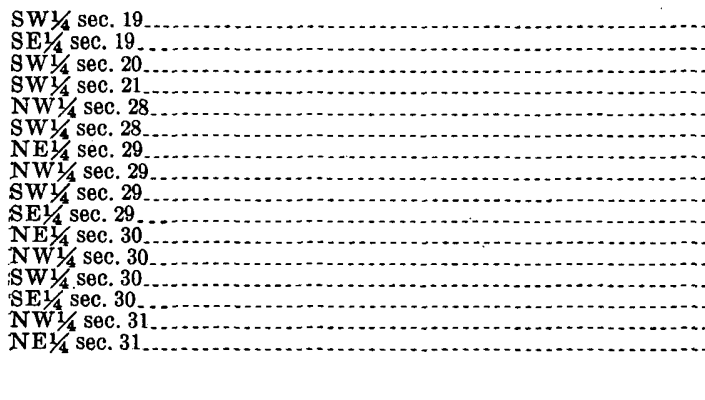 } & \multirow[t]{2}{*}{\begin{tabular}{|l} 
June 1925 \\
June 1926 \\
March 1933 \\
June 1924 \\
January 1923 \\
March 1924 \\
July 1923 \\
January 1925 \\
October 1926 \\
July 1924 \\
January 1926 \\
June 1927 \\
\\
September do \\
December 1926 \\
\end{tabular}} & $\begin{array}{r}1197,754 \\
166,741 \\
4,240 \\
2226,039 \\
3217,642 \\
41,409 \\
1,823,224 \\
930,396 \\
145,713 \\
118,427 \\
1,029,430 \\
541,946 \\
1,105,937 \\
813,807 \\
694,764 \\
306,115\end{array}$ \\
\hline & & $8,223,584$ \\
\hline
\end{tabular}

1 To Dec. 31, 1937

2 Abandoned in 1930 .

3 A bandoned in 1933 .

- A bandoned in April 1928.

A prominent dome called the Whitecliff dome by Heald and Mather ${ }^{24}$ occupies parts of secs. $27,28,33$, and 34 . The closure is 40 feet on the exposed beds ${ }^{25}$ and 170 feet on the Oswego lime (pl. 3). The crest of

"Heald, K. O., and Mather, K. F., op. cit., p. 163.

${ }^{25}$ Idem. 
the dome on the Oswego lime is a short distance west of the crest on the exposed rocks.

Of the 28 wells drilled on the Whitecliff dome, 15 tested all beds down to the upper part of the Ordovician rocks. Six wells near the crest of the dome yielded oil from Ordovician rocks at depths of about 2,700 feet. A microscopic examination of samples from 2 wells and the drillers' logs of other wells indicate that the oil occurs in the top few feet of the Siliceous lime beneath sand and shale, about 30 feet thick, of the Simpson formation. The log of well 1 in the northwest corner of the $\mathrm{SW} 1 / 4 \mathrm{sec}$. 34 records a show of oil 120 feet below the top of the Siliceous lime. This show of oil is noteworthy because no oil in commercial quantities is known to occur in Osage County so far below the top of the lime. Few producing wells penetrate more than the uppermost 50 feet of the lime.

The initial yields of the wells ranged from 20 to 7,800 barrels a day, and each well produced much of its total yield during the first year of its life. Two Siliceous lime oil wells in the SW $1 / 4$ sec. 27 produced a total of 591,725 barrels, and all but 56,963 barrels. were produced in 1924. One well began producing in January and the other in May 1924. The total yield from the $\mathrm{NE} / 4$ sec. 33 was 71,780 barrels, 68,146 barrels of which was produced by well 1 during 4 months in 1924. The total yield from the $\mathrm{NW} / 4$ sec. 34 had been 715,439 barrels at the end of 1937 .

Gas with daily initial volumes ranging from 750,000 to $2,000,000$ cubic feet was produced in two wells from chert about 25 feet below the top of the Mississippi lime, which in this report is included in the Burgess sand-Mississippi lime zone. Several other wells had shows of oil or gas in this chert. It is noteworthy that well 2-350 in the center of the SW $1 / 4 \mathrm{SW} 1 / 4$ sec. 27 , not far below the crest of the dome, yielded a hole full of water in the Burgess sand-Mississippi lime zone, but well 351 in the $\mathrm{NW} / 4 \mathrm{SW} 1 / 4$ sec. 27 , low on the north flank of the dome yielded gas from this zone. Relatively large shows of gas were found in several wells in the Oswego lime and in the Big lime. Well 311 in the northwest corner of sec. 34 yielded gas at an initial rate of $9,800,000$ cubic feet a day from the Oswego lime at a depth of 2,000 feet. Two gas wells (Nos. 307 and 308) one of which yielded initially $4,000,000$ cubic feet a day, were completed in the Mussellem and Peoples sand zone at depths of about 1,225 feet. Both wells, after producing for a time, were deepened; one produces gas from the Big lime and the other from the Oswego lime. The Big lime well was given acid treatment, following which it yielded 9,800,000 cubic feet a day. Sand in the lower part of the Okesa, Torpedo, and Clem Creek sand zone yielded shows of gas in 12 wells and produced gas in 2 wells at depths of about 1,050 feet. The maximum yield of one of the producers was $11,000,000$ cubic feet a day. Four wells in the SW $1 / 4$ sec. 27 produced 
gas from sand in the lower part of the Nelagoney formation at a depth of about 650 feet. The sand is tentatively identified as the Cheshewalla sand. Several other wells found shows of gas in this bed.

The subsurface investigation of the Whitecliff dome indicates that it has been adequately tested for oil, but additional gas wells with small yields probably could be obtained.

\section{MAYER ANTICLINE}

The Mayer anticline trends slightly soutb of west across sec. 24, into the $\mathrm{SE} 1 / 4$ sec. 23. On the east it joins the Okay anticline, which trends northward through secs. 31, 30, and 19 of T. 25 N., R. 9 E., and is separated from the Mayer anticline by a shallow structural saddle. On the exposed rocks the Mayer anticline forms a westwardplunging anticlinal nose that has no closure on the east. ${ }^{26}$ Deep synclines border the combined Mayer-Okay anticlinal fold on all sides.

The Mayer anticline has been tested by 22 wells in T. $25 \mathrm{~N}$., R. $8 \mathrm{E}$; 15 of the wells produced oil from the Burgess sand-Mississippi lime zone at depths of about 2,300 feet. The oil-bearing bed is chert and cherty limestone, recorded in the logs as sand, 10 to 35 feet below the top of the Mississippi lime. Two of the wells yielded initially 80 barrels a day, but the average initial yield was only about 40 barrels. The reservoir rocks were treated with acid in three wells in the SE1/4 sec. 23. The total yield from the $\mathrm{SE} / 4$ sec. 23 was 142,368 barrels on Nov. 30, 1937. Oil was first produced here in July 1920. The total yield from the SE $1 / 4$ sec. 24 was 240,998 barrels on Dec. 31, 1937. Only 311 barrels was produced from the NE $1 / 4$ sec. 24 .

Well 2 in the $\mathrm{SE} 1 / 4 \mathrm{NE} 1 / 4 \mathrm{SE} 1 / 4$ sec. 24 produced at the rate of 5 barrels of oil a day from sand in the uppermost part of the Big lime, at a depth of 1,700 feet. Shows of oil or gas were recorded in the Big lime and in the Peru sand in the logs of several wells. Three wells, one of which produced oil from the Burgess sand-Mississippi lime zone, tested also Ordovician rocks but found no oil or gas. None of these wells, however, is on the crest of the fold. Three Burgess sandMississippi lime zone producers were drilled recently in the SE 14 sec. 24 , and it is probable that others will be drilled in the $\mathrm{W} / 2 \mathrm{SE} 1 / 4$ and $\mathrm{SE} / 4 \mathrm{SE} / 4$ sec. 24. The structure of the Oswego lime as shown on plate 3 indicates that the Siliceous lime should be tested near the center of the $\mathrm{NW}^{1 / 4} \mathrm{NW}_{4}^{1 / 4} \mathrm{SE}^{1 / 4}$ sec. 24.

\section{RODEO ANTICLINE}

The Rodeo anticline is a broad low fold that occupies parts of several sections in the northeastern part of the township. The structure of the buried rocks as shown on plate 3 is similar to that of the exposed

${ }^{20}$ Heald, K. C., and Mather, K. F., in White, David, and others, Structure and oil and gas resources of the Osage Reservation, Okla.: U. S. Geol. Survey Bull. 686, pl. 24, 1922. 
rocks except that the crest of the anticline on the buried rocks is slightly west of its position on the exposed rocks. ${ }^{27}$ Of a total of 20 wells on the Rodeo anticline, 19 reached the Mississippi lime at a depth of about 2,400 feet, and 10 wells produced oil from the Burgess sand-Mississippi lime zone. It is noteworthy that many of the producing wells are well down on the flanks of the anticline and several dry holes are structurally higher than the producers. The producing wells had an average initial yield of about 40 barrels a day, but a few yielded 100 barrels. The wide distribution of the producing wells indicates that other parts of the anticline will be found productive of oil in the Burgess sand-Mississippi lime zone. Wells having only a small daily yield should be expected. Moreover, small total yields for new wells are indicated by the small total yields made to date by the producing wells on the Rodeo anticline. The NE/4 sec. 3, which began producing in January 1923, had produced 42,680 barrels on December 31, 1937. The NW1/4 sec. 3 yielded 3,259 barrels from May 1921 to September 1926. The SW $1 / 4$ sec. 11, which began producing in June 1921, had produced 29,451 barrels on November 30, 1937, and the $\mathrm{SE}^{1 / 4}$ sec. 10, which began producing in August 1920 had produced 35,437 barrels on November 30, 1937.

Four wells on the Rodeo anticline tested Ordovician rocks. Only one well produced oil from these beds, however. The producer is well 3 near the center of the $\mathrm{N} \frac{1}{2} \mathrm{SE} \frac{1}{4}$ sec. 10 , in the structural saddle that separates two subsidiary domes on the anticline. It is reported that the well produced 40 barrels of oil a day from the Siliceous lime. Inasmuch as the oil in Ordovician rocks in this region appears to be confined to relatively small tracts on the highest parts of sharply folded domes, it is possible that oil occurs in Ordovician rocks on or near the crests of the two domes that are superposed on the anticline.

Some wells found shows of oil and gas in several beds in Pennsylvanian rocks. Therefore, when additional wells are drilled shows should be expected in several beds, particularly in the Big lime, and in the Okesa, Torpedo, and Clem Creek sand zone. The possibility of developing a gas field in one or more of the sands of the Okesa, Torpedo, and Clem Creek sand zone is promising.

\section{POLLEDOAK DOME}

The crest of the Polledoak dome is near the southeast corner of sec. 9 on the exposed rocks ${ }^{28}$ and is shown on plate 3 to be about half a mile northwest of that locality on the top of the Oswego lime. Little confidence can be placed in this part of plate 3 , however, because the positions of the contours are based on very few datum points; the dome as shown is hypothetical. Several faults cut the surface rocks,

${ }^{27}$ Heald, K. C., and Mather, K. F.,.op.cit.

as Idem. 
but the data were insufficient to determine whether deeply buried rocks, including the Oswego lime, are displaced by the faults.

The Polledoak dome has been tested by 11 wells, 3 of which produced a small amount of oil. The Clem Creek sand is the oldest rock tested in two of the wells. One of these shallow wells produced 12 barrels of oil a day from the Clem Creek sand encountered at a depth of 1,065 feet. Nine wells tested the Burgess sand-Mississippi lime zone at a depth of about 2,375 feet, and only 2 of these produced oil. One well producing from the Burgess sand-Mississippi lime zone yielded initially 43 barrels a day. Four dry holes were drilled into Ordovician rocks, but none of these was on the crest of the dome as shown on plate 3 . Well 1 in the $\mathrm{SE} 1 / 4$ sec. 9, however, was located a short distance northwest of the crest of the dome in the exposed rocks. ${ }^{29}$

Commercial amounts of gas might be developed on the Polledoak dome at depths of 900 to 1,000 feet in sand near the middle of the Okesa, Torpedo, and Clem Creek sand zone, because shows of oil and gas in this zone are recorded in the logs of several wells.

\section{CLEAR CREEK DOMES}

The subsurface mapping of the Clear Creek domes in the northwestern part of the township is mainly hypothetical because only meager subsurface data are available. The positions of the contours shown on plate 3 were determined largely from the structure contour map of the exposed rocks. ${ }^{30}$ Two deep dry holes, one in the SE1/4W 314 sec. 5 and the other in the $\mathrm{NE}_{1}^{1} / 4 \mathrm{SE} 1 / 4$ sec. 7 , have been drilled on the northeastern one of the two domes. According to the log, the well drilled in the $\mathrm{SE}_{1 / 4}^{1 / \mathrm{SW}} 1 / 4$ sec. 5 found a show of oil at a depth of 1,870 feet in sand that is probably equivalent to the Wayside sand. The $\log$ records also a small show of gas in the Big lime at a depth of 1,935 feet. The well in the $\mathrm{NE}_{4}^{1 / \mathrm{SE}^{1 / 4}}$ sec. 7 found a show of gas in the Clem Creek sand at a depth of 1,180 feet, a small show of oil in the Mussellem and Peoples sand zone at a depth of 1,450 feet, and a small show of oil in the Simpson formation at a depth of 2,773 feet.

\section{T. 24 N., R. 9 E.}

T. 24 N., R. 9 E., is in central Osage County, 41/2 miles south of Pawhuska, the county seat. Wynona lies near the center of the township. The township is on the northwestern margin of a region containing many oil pools in the Bartlesville sand. Oil or gas has been produced in the township from 10 zones at depths ranging from about 700 to 2,500 feet, and large shows of gas have been found at a depth of 300 feet. The Bartlesville sand is the producing sand in

${ }^{29}$ Heald, K. C., and Mather, K. F., in White, David, and others, Structure and oil and gas resources of the Osage Reservation, Okla.: U. S. Geol. Survey Bull. 686, pl. 24, 1922.

${ }^{80}$ Idem. 
most of the wells. A few localities that are prospectively valuable for oil and gas remain to be tested.

Oil was first produced in T. 24 N., R. 9 E., in 1906 when well 1 in the southeast corner of the NE $1 / 4$ sec. 25 was completed. Most of the wells in the township, however, were drilled subsequent to 1918. The large Wynona field in the eastern part of the township was developed mainly from 1918 to 1920 , although most of the wells in the NE ${ }^{1 / 4}$ sec. 27 and the NW1/4 sec. 26 were drilled in 1922 . The wells in sec. 1, in the southwestern part of the Pershing field, were drilled from 1918 to 1920. Most of the wells in secs. 3, 9, and 10 were drilled in 1919 and 1920. Several wells in secs. 5 to 8 were drilled in 1928 and 1929. Most of the wells on the Bulldog anticline were drilled from 1920 to 1927 , although three wells were drilled on the southeast flank of the anticline in 1938. Most of the wells on the Pipeline anticline were drilled from 1924 to 1926 . One producing oil well was drilled on the Bandwheel dome in 1920, and the others were drilled from 1922 to 1924.

The subsurface investigation of T. 24 N., R. 9 E., was made in 1935 mainly by L. E. Kennedy. The statistics of the oil production of many leases were compiled in part by Otto Leatherock in 1935 and in part by Miss Anna L. Weinrich, of the Osage Indian Agency, in 1938.

\section{STRUCTURE AND DEVELOPMENT}

T. 24 N., R. 9 E., lies along the eastern margin of a belt of country about 15 miles wide that is characterized by pronounced folds and extends northeastward from western Creek County to a point a few miles north of Pawhuska. The Oswego lime, which lies at a depth of about 1,800 feet, has a regional westward dip of about 200 feet across T. 24 N., R. 9 E. The regional dip is interrupted by several pronounced anticlines, domes, and synclines, the most prominent of which are the Fourmile and Bandwheel domes, West Birdseye, Cottonmouth, Postoak, Bulldog, and Pipeline anticlines, the basin between the Postoak and Cottonmouth anticlines and the deep syncline a short distance north of the middle of the township.

The main structural features of the buried rocks as shown by the structure contours drawn on the top of the Oswego lime (pl. 3) are reflected by the attitude of the surface rocks. ${ }^{31}$. In general, the dip of the buried rocks is steeper than that of the surface rocks, and the crests of most of the folds in the buried rocks are not directly beneath the crests of the folds on the exposed rocks. The exposed rocks in a belt that extends northeastward through the central part of the township are broken by a series of faults that trend northwest. The maximum vertical displacement of the exposed rocks is about 40 feet.

${ }^{31}$ Heald, K. C., and Bowen, C. F., in White, David, and others, Structure and oil and gas resources of the Osage Reservation, Okla.: U. S. Geol. Survey Bull. 686, pl. 32, 1922. 
The faults are not shown on plate 3 because the data were insufficient to determine whether they cut the deeply buried rocks. The few data available suggest, however, that the deeply buried rocks are not cut by the faults.

\section{WEST BIRDSEYE ANTICLINE, FOURMILE DOME, AND DOME IN SECS. 23 AND 26 (WYNONA FIELD)}

The West Birdseye anticline in secs. 13, 14, and 24, the Fourmile dome in secs. 25,26 , and 36 , and the dome in secs. 23 and 26 with the synclines that lie between them occupy most of the area of the Wynona oil and gas field. The structural closure of the West Birdseye anticline is about 100 feet on the top of the Oswego lime (pl. 3) and is only about 20 feet on the exposed rocks. ${ }^{32}$ The crest of the fold on the Oswego lime appears to lie directly beneath the crest on the exposed rocks, a relationship uncommon for folds in the region. Furthermore, the anticline contains two subsidiary domes each having a structural closure of from 35 to 40 feet on the Oswego lime, but these domes are not apparent on the exposed rocks. The crest of the Fourmile dome and the crest of the small dome in the NE1/4 sec. 26 on the Oswego lime lie about 1,000 feet northwest of their respective positions on the exposed rocks.

About 280 producing oil or gas wells have been drilled in the Wynona field. Of these wells, 263 produced oil or gas from the Bartlesville sand, 12 from the Wayside sand, 3 from the Burgess sand-Mississippi lime zone, 1 from the Layton sand, and 1 from the Big lime.

The Bartlesville sand, which lies at a depth of about 2,050 feet, ranges from about 30 to 170 feet in thickness, but most producing wells penetrated the sand only about 60 feet. The initial yields of the 248 oil wells that produced from the Bartlesville sand ranged from 10 to 2,000 barrels a day, and the initial yields of the 15 gas wells ranged from 2,000,000 to $25,000,000$ cubic feet of gas a day. The initial yields of most of the oil wells, however, was less than 100 barrels. Wells that produced only gas from the Bartlesville sand are restricted to the higher parts of the West Birdseye anticline and to the Fourmile dome. It is noteworthy that the synclinal area between the West Birdseye anticline and the Fourmile dome is the most productive part of the field; also, that the average initial yield of the wells in this area was larger than in most other parts of the field.

The first oil in the Wynona field was obtained September 8, 1905, by the Barnsdall Oil Co. from their No. 1 well in the SW1/4 SW $1 / 4 \mathrm{NW} 1 / 4$ sec. 30 , T. 24 N., R. 10 E., which had an initial daily production of 75 barrels from the Bartlesville sand. The Winona Oil Co. completed

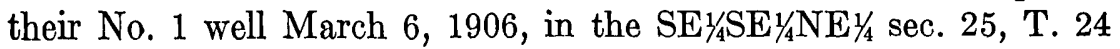
N., R. 9 E., and obtained an initial daily production of 50 barrels of

22 Heald, K. C., and Bowen, C.F., op. cit., pl. 32. 
oil from the Bartlesville sand. But little additional development took place in the Wynona field until 1917, when 7 wells were producing. The most intensive drilling took place in 1919 and 1920, when about 100 producing wells were completed during each year. A total of 293 wells were producing in 1924 . The peak of production was reached in 1920, when $1,349,427$ barrels of oil was produced during that year. The oil-bearing sand is being repressured with gas in a part of the field. Records of oil produced prior to July 1, 1916, are not available, but the total production from July 1, 1916, to Dec. 31, 1934, was 6,969,527 barrels according to data compiled by Otto Leatherock from records of the Osage Indian Agency. Leatherock estimated the total producing area in the Wynona field as 2,445 acres. The total recovery to the acre therefore was 2,810 barrels on Dec. 31 , 1934. The most productive tracts and the total amount produced from each tract by Dec. 31, 1934, are as follows:

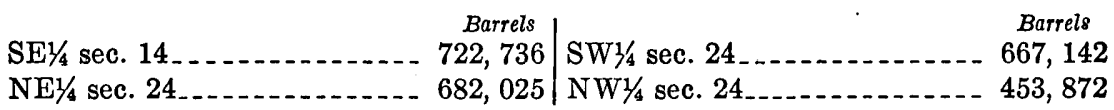

Although positive recommendations for new drilling cannot be made in this area without investigating the recent production performance of the wells, which was not done for this report, suggestions that are worthy of investigation will be made. The logs indicate that wells 1 to 3 and 5 to 7 in the NW1/4 sec. 13 were abandoned without testing the lower part of the Bartlesville sand. Each of these wells had initial yields of only 10 to 50 barrels a day, but it is probable that larger yields could have been obtained by drilling the wells deeper into the sand. Well 4 encountered water at an altitude of 1,245 feet below sea level, and if the water in this well is indicative of a water level in this area wells 1 to 7 could have been deepened from 40 to 80 feet before encountering water. It appears that wells 3 to 11 inclusive in the SW $1 / 4$ sec. 13 could have been drilled from 30 to 100 feet deeper without encountering water.

It is probable that several of the abandoned wells in the $\mathrm{SE} / 4 \mathrm{sec}$. 13 should have been deepened into lower oil-bearing sand. The logs of wells 1 and 2 show two or more shale beds 15 to 20 feet thick in the upper part of the Bartlesville sand. Both wells found some water in the upper sand, but this show of water is not proof that oil does not occur in lower beds of the Bartlesville sand.

The distribution of the wells and the thickness of the Bartlesville sand in the $\mathrm{NE}_{1 / 4}$ and $\mathrm{E} / 2 \mathrm{NW} 1 / 4$ sec. 14 suggest that more wells should be drilled there. Logs of wells in the SW1/4 sec. 14 show that the sand becomes thinner southwestward from the crest of the anticline and indicates that the southwestern margin of the producing area has been determined. The distribution of the producing wells in sec. 23 indicates that more wells should be drilled to the Bartlesville sand in 
the $\mathrm{NE} 1 / 4$ and $\mathrm{S} 1 / 2$ sec. 23. The logs of wells in the $\mathrm{S} 1 / 2$ sec. 23 show that the sand has a thickness of 50 to 120 feet. Well 39 in the south-central part of the SW 14 sec. 23 is reported to have had an initial daily production of 250 barrels, but no offset wells have been drilled to the north, east, or west of this well. Wells 36 and 37 , which are near well 39, each produced initially 200 barrels a day, and well 38 produced 125 barrels. These wells were drilled in 1921 and 1922.

The distribution of producing wells and abandoned producers in the NW $1 / 4$ sec. 25 and the $\mathrm{S} 1 / 2$ sec. 25 indicates that additional wells with small yields could be obtained in the undrilled parts of these tracts. Nearly all of sec. 26, with the exception of a part of the SWY, and a part of the NW1/4 sec. 36 should produce oil or gas from the Bartlesville sand.

The Jones and Cleveland sand zone produced oil in 12 wells in the Wynona field. Half of these wells are on the southeast flank of the Fourmile dome, and the others are somewhat widely distributed. The initial production of the wells ranged from 5 to 600 barrels of oil a day, but except for 1 well in the $\mathrm{SE} 1 / 4$ sec. 25 , which produced 600 barrels, the average initial production per well was about 25 barrels. The producing sand ranges from 20 to 45 feet in thickness and lies at depths of about 1,375 feet.

Two wells in the SE1/4 sec. 25, on the Fourmile dome, produced gas, and 1 well on the dome in the $\mathrm{NE}^{1 / 4}$ sec. 26 produced oil from the Burgess sand-Mississippi lime zone. The gas wells yielded initially $3,000,000$ and $5,000,000$ cubic feet a day, and the oil well yielded 5 barrels. No commercial quantities of oil or gas were found in 17 other wells in the Wynona field that tested the Burgess sand-Mississippi lime zone.

Well 1 in the southeast corner of the $\mathrm{NE} 1 \%$ sec. 14 had an unusually large initial yjeld from the Big lime at a depth of 1,520 feet. The well's initial yield was estimated to be 2,000 barrels, but after a few days it declined to a small flow. Well 10 in the $\mathrm{NE}_{1 / 4} \mathrm{NW} / 4 \mathrm{SW} 1 / 4$ sec. 25 had a reported initial production of 175 barrels a day from the Layton sand at a depth of 1,035 feet, and several other wells in secs. 25 and 26 recorded shows of oil in the Layton sand. Therefore, when additional wells are drilled, shows of oil in the Layton sand should be tested, because elsewhere in Osage County profitable wells have been obtained by shooting this sand after finding relatively small shows of oil.

Ordovician rocks have been tested in only six wells in the Wynona field, and only two of the wells were structurally high. Inasmuch as wells with large yields have been found in Ordovician rocks in this region it would appear that these rocks should be tested near the center of the $\mathrm{SE}_{1 / 4} \mathrm{SW} 1 / 4$ sec. 25 on the Fourmile dome and on the two subsidiary domes on the West Birdseye anticline. 
WYNONA ANTICLINE

In the vicinity of Wynona the rocks are folded into two small domes that together form the Wynona anticline. The top of the Oswego lime appears to have a closure of about 50 feet (pl. 3) on the north dome, and the exposed rocks have a closure of 20 feet or less. ${ }^{33}$ The Oswego lime is 120 feet lower structurally on the crests of the domes on the Wynona anticline than on the crest of the West Birdseye anticline, which lies $1 \frac{3}{4}$ miles to the northeast.

Oil has been found in the Bartlesville sand in several wells on the Wynona anticline at depths of about 2,150 feet. The Burgess sand Mississippi lime zone has been tested in several wells, and Ordovician rocks have been tested near the crest of each dome. It is reported that well 1 on the crest of the south dome produced 500 barrels of oil a day from Ordovician rocks encountered at depths of 2,506 to 2,514 feet and produced water from depths of 2,510 to 2,514 feet. A total of 34,774 barrels of oil was produced from the SW $1 / 4$ sec. 22 from July 1920 to the end of 1937, and 23,700 barrels was produced from the $\mathrm{SE} / 4$ sec. 22 from September 1921 to the end of 1937. Doubtless additional oil wells could be found in the Bartlesville sand. Inasmuch as the wells near the center of sec. 22 produced initially about 75 to 125 barrels a day, producing wells should be expected north and south of these. In fact, most of sec. 22 and at least the NE1/4 sec. 27 are prospectively valuable for oil in the Bartlesville sand, but wells with small daily yields should be expected.

\section{BANDWHEEL DOME}

The crest of the Bandwheel dome on the Oswego lime in sec. 33 lies about 1,000 feet northwest of its position on the exposed rocks. Ordovician rocks have been tested by dry hole No. 2 near the crest of the dome and by well 5 on the northwest flank. The Burgess sandMississippi lime zone has been tested by two dry holes on the crest, by No. 5 on the northwest flank, and by a well in the $\mathrm{NE}_{1 / 4}^{1 / 2 W} \mathrm{NW}_{4} \mathrm{NE} 1 / 4$ sec. 33 low on the north flank of the dome. The Bartlesville sand yielded oil in seven wells on the west and southwest flanks of the dome. Five of these wells were drilled from 1922 to 1924 and are still producing, and an additional well (No. 5) produced from the Bartlesville sand until 1935, when it was deepened to the Siliceous lime. Only 20 barrels a day was produced after the Siliceous lime was acidized. Although the dry holes that lie east and south of wells producing from the Bartlesville sand appear to define the boundaries of the Bartlesville producing area on the east and south, the field could probably be extended to the north, west, and southwest. However, wells with small daily yields should be expected. The total yield from the NW1/4 sec. 33 was 96,000 barrels at the end of 1937 . The first wells began producing in August 1922.

w Heald, K. C., and Bowen, C. F., op. cit., pl. 32. 
PIPELINE ANTICLINE

The Pipeline anticline in sec. 32 shows a wide departure on the buried rocks (pl. 3 ) from its position and shape on the exposed rocks. ${ }^{34}$ The crest of the dome on the Oswego lime is a little more than half a mile southwest of its position on the exposed rocks. The structural closure on the Oswego lime exceeds 100 feet. The positions of the structure contours in the $\mathrm{E} / 2$ sec. 29 were inferred from the map ${ }^{35}$ showing the attitude of the exposed rocks, because no subsurface datum points are known. The northeastward-trending prong of the Pipeline anticline shown on plate 3 in the E $1 / 2$ sec. 29 is therefore speculative and probably is a poor representation of the structure of the buried rocks. The structure of the exposed rocks suggests that it is not improbable that a dome is present in some part of the $\mathrm{E} 1 / 2$ sec. 29 , but its precise location is unknown.

The total amounts of oil that had been produced from the Pipeline anticline by December 31, 1937, are shown in the following table prepared from records of the Osage Indian Agency:

Oil produced from the Pipeline anticline

\begin{tabular}{|c|c|c|}
\hline Tract & $\begin{array}{l}\text { Date of first } \\
\text { production }\end{array}$ & $\begin{array}{l}\text { Production to } \\
\text { end of 1937 } \\
\text { (barrels) }\end{array}$ \\
\hline $\begin{array}{l}\text { SW1/4 sec. } 29 \\
\text { NE1/4 sec. } 32 \ldots \\
\text { NW1/4 sec. } 32 \\
\text { SW 1/4 sec. } 32 \\
\text { SE1/4 sec. } 32\end{array}$ & $\begin{array}{l}\text { February } 1920 \\
\text { July } 1925 . \\
\text { June } 1923 \\
\text { October } 1926 \\
\text { February } 1924\end{array}$ & $\begin{array}{r}104,084 \\
43,837 \\
218,658 \\
100,758 \\
20,943\end{array}$ \\
\hline & & 488,280 \\
\hline
\end{tabular}

Oil or gas is produced on the Pipeline anticline from eight zones that range in depths from about 700 to 2,500 feet. Five wells, two of which were later abandoned, produced oil at initial daily rates ranging from 30 to 2,500 barrels from Ordovician rocks. It was not determined whether the oil occurs in the Simpson formation or in the Siliceous lime, but the logs indicate that it is in the uppermost beds of the Siliceous lime. Five wells produced oil and two wells produced gas from the Bartlesville sand at depths of 2,050 to 2,200 feet. The oil wells produced initially from 25 to 100 barrels a day, and the gas wells produced from $11,000,000$ to $12,000,000$ cubic feet a day. The gas occurs in the upper part of the Bartlesville sand, which is from 50 to 100 feet thick, and it is possible that the gas wells could be converted into oil wells by deepening them. Well 4 in the $\mathrm{SW}_{1 / 4}^{1 / \mathrm{SE}_{1 / 4}^{1 / 4}} \mathrm{SW}_{1 / 4}^{1 / 4}$ sec. 29 produces oil and gas from the Skinner sand, which is 17 feet thick and lies at a depth of 2,010 feet. The logs of most wells on the

34 Heald, K. C., and Bowen, C. F., op. cit., pl. 32.

${ }^{35}$ Idem. 
Pipeline anticline record shale at the position of the Skinner sand, although about half a dozen logs record sand, and two record shows of oil in the sand.

Recently two oil producers bave been completed in the Oswego lime after treating the oil-bearing beds with acid. Nine wells on the south and southeastern parts of the anticline produce oil from the Wayside (locally called Cleveland) sand. The initial yields of the wells ranged from 15 to 30 barrels. The Wayside sand is about 30 feet thick and lies at a depth of about 1,550 feet. The Jones and Cleveland sand zone, which is about 50 feet thick and is separated from the Wayside sand by a shale bed 25 to 30 feet thick, yields shows of gas and oil in many wells.

The Layton sand yields oil at daily rates that range from 10 to 150 barrels in three wells on the southeast flank of the anticline. Several other wells also found shows of oil and gas in the Layton sand. Well 8, near the center of the $\mathrm{SE}_{1} / \mathrm{NW}_{1 / 4}$ sec. 32 , produces oil from sand that lies near the base of the Okesa, Torpedo, and Clem Creek sand zone and therefore is tentatively called the Clem Creek sand. Well 435 near the center of the $\mathrm{NE}_{1 / 4}^{1} \mathrm{NW}_{1 / 4}$ sec. 32 yields gas from sand that lies in the upper part of the Okesa, Torpedo, and Clem Creek sand zone, about 200 feet above the oil-bearing sand found in well 8 . This gasbearing sand may be equivalent to the Okesa sand or possibly to the Torpedo sand. Many other wells on the dome found shows of oil and gas in the Okesa, Torpedo, and Clem Creek sequence of sands. Although the data derived from the deep wells indicate that the distribution of the oil-bearing Bartlesville sand is irregular here, the wide distribution of the wells in secs. 29 to 32 that found oil in the Bartlesville sand indicates that the sand may be oil-bearing throughout a broad area that includes sec. 32 and the $\mathrm{S}_{1 / 2}$ sec. 29. Additional wells with small daily yields probably can be obtained on the Pipeline anticline in the Oswego lime by acidizing the oil-bearing beds. The total area occupied by oil-bearing Wayside sand has not been defined, and additional gas production probably can be developed in the sands of the Okesa, Torpedo, and Clem Creek sand zone, which lie at shallow depths.

SECS. 30 AND 31

The North Manion anticline is a prominent fold that trends northeastward through the northeastern part of T. 23 N., R. 8 E., and the northwestern part of T. 23 N., R. 9 E., into sec. 31, T. 24 N., R. 9 E..$^{36}$ Oil and gas are produced from Ordovician rocks and from the Burgess sand-Mississippi lime zone on the crest of the anticline, less than a mile south of the southwest corner of sec. 31 , T. 24 N., R. 9 E. Ten wells in the N1/2 sec. 6, T. 23 N., R. 9 E., and the SE $1 / 4$ sec. 31, T. 24 N.,

${ }^{20}$ Kirk, C. T., and others, Subsurface geology and oil and gas resources of Osage County, Okla., pt. 2, Townships 22 and 23 North, Ranges 8 and 9 East: U. S. Geol. Survey Bull. 900-B, pl. 2 (in press). 
R. 9 E., on the northeast flank of the anticline, produce oil from the Bartlesville sand. The initial daily yjelds of the wells ranged from about 25 to 200 barrels. Between half a mile and a mile northwest of these wells six other wells in the NW1/4 sec. 31 and the SW11/4 sec. 30 , on the northeast flank of the Thirty-six anticline, yield oil from the Bartlesville sand. The initial daily yields of these wells ranged from 5 to 400 barrels. The distribution of the wells and the regional habits of occurrence of oil in the Bartlesville sand indicate that many other producing wells could be drilled in the $\mathrm{S} 1 / 2$ and $\mathrm{NW} 1 / 4$ sec. 31 , but the daily yields of the wells probably would be small.

\section{BULLDOG ANTICLINE}

An irregular, somewhat crescent-shaped anticline, named the Bulldog anticline by Heald and Bowen, ${ }^{37}$ occupies parts of several sections a short distance southwest of the center of T. 24 N., R. 9 E. The exposed rocks are arched into an anticline that in its general shape is similar to the anticline on the Oswego lime but in its subsidiary features is quite dissimilar.

Thirty-three wells on this anticline have produced oil, and one well has produced gas. All but three of the oil wells produced from the Bartlesville sand; two wells produced from the Peru sand, and one from the Oswego lime. The initial yields of the Bartlesville sand oil wells ranged from 20 to 1,000 barrels a day, and the initial yield of the abandoned gas well in the SW $1 / 4$ sec. 17 was $2,000,000$ cubic feet a day. The thickness of the Bartlesville sand ranges from 10 to 125 feet and appears to average about 80 feet. The sand lies at a depth of about 2,200 feet. In most wells the upper part of the sand yields gas and the lower part yields oil. The development of the oil field thus far is limited to the higher parts and the south flank of the anticline. Well 3 in the SW $1 / 4$ sec. 21 and well 8 in the SE1/4 sec. 20 were drilled early in 1938, although wells that offset them on the north and west had been producing oil for 15 years. Well 3 produced 90 barrels a day initially, and well 8 produced 60 barrels.

The dry holes in the southeast corner of sec. 18 and the southeast corner of the NE $y_{4}^{\prime}$ sec. 19 indicate that the Bartlesville sand pinches out in the westernmost part of secs. 17 and 20. The log of the dry hole in the southwest corner of sec. 16 shows the Bartlesville sand to be composed of several thin beds of sand separated by shale. Wells 1 and 2 in the $S W 1 / 4 \mathrm{NW}_{1 / 4}$ sec. 21 produced initially 1,000 barrels a day. These facts and the distribution of the producing wells in the field indicate that the oil-producing area might be extended in the $\mathrm{S} 1 / 2$ sec. 17 and throughout much of sec. 20 and a part of the W3/2 sec. 21.

"Heald, K. C., and Bowen, C. F., op. cit., pl. 32. 
Wells 1 and 2 in the NW1/4 sec. 20 produced initially 15 and 30 barrels of oil a day respectively from the Peru sand at a depth of 1,775 feet. Well 4 in the southeast corner of the SW $1 / 4$ sec. 17 yields oil from the Oswego lime. Shows of oil and gas were found in the Wayside sand, and shows of gas were found in a few wells in a sand that is tentatively identified as the Torpedo sand. Ordovician rocks have been tested by well 5 in the SW $1 / 4$ sec. 17, which found a show of gas in these rocks, and by well 7 in the $\mathrm{NE}_{4}^{\prime \prime}$ sec. 20 .

The total amount of oil that had been produced from the Bulldog anticline by December 31, 1937, is shown in the following table, which was prepared from records of the Osage Indian Agency:

Oil produced from the Bulldog anticline

\begin{tabular}{|c|c|c|}
\hline Tract & Date of first produc- & $\begin{array}{l}\text { Production } \\
\text { to end of } 1937 \\
\text { (barrels) }\end{array}$ \\
\hline \multirow[t]{2}{*}{ 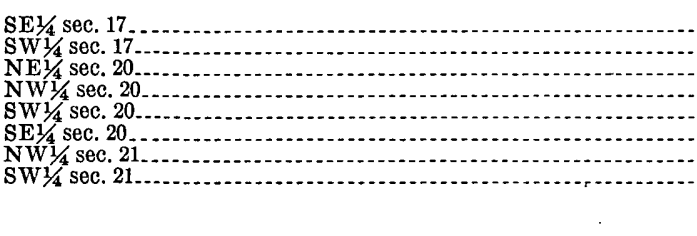 } & 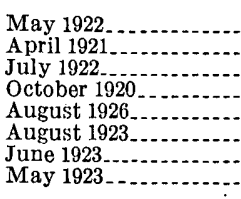 & $\begin{array}{r}81,609 \\
89,539 \\
134,897 \\
61,783 \\
283,552 \\
178,519 \\
79,194 \\
22,390\end{array}$ \\
\hline & & 931,483 \\
\hline
\end{tabular}

POSTOAK ANTICLINE AND DOME IN SEC. 8

The Postoak anticline occupies parts of secs. 5, 6, and 7. It is separated from the Wooster anticline in T. 25 N., R. 9 E., by a structural saddle in the $\mathrm{NW}_{1 / 4}$ sec. 5. The positions of the structure contours for this area shown on plate 3 are speculative because only a few wells that reveal the position of the Oswego lime have been drilled. The positions of the structure contours in much of this area are inferred, therefore, from the structure contour map of the exposed rocks. ${ }^{38}$ It is not at all unlikely that a dome is present in the NE1/4 sec. 7 on the crest of the Postoak anticline. Also, the saddle that lies between the Postoak anticline and the dome in sec. 8 may be deeper than shown on plate 3 . On the Postoak anticline three wells produce gas and one well produces oil, and on the dome in sec. 8 three wells produce gas and a fourth well produced gas for a time. The Oswego lime at a depth of about 1,900 feet is the gas-bearing bed in most wells. Two wells on the dome in sec. 8 yield gas at a depth of about 700 feet from sand in the Okesa, Torpedo, and Clem Creek sand zone. These two wells produced initially at rates of $3,000,000$ and $5,250,000$ cubic feet a day. The Oswego lime gas wells produced initially at rates of $2,000,000$ to $8,250,000$ cubic feet a day. Several wells had shows

${ }^{a}$ Heald, K. C., and Bowen, C. F., op. cit., pl. 32. 
of gas ranging from 250,000 to $1,250,000$ cubic feet, in sand at a depth of about 300 feet near the position of the Cheshewalla sand. A few wells had shows of gas in the Layton sand at a depth of about 1,300 feet, and a few had shows of oil and gas in the Burgess sand-Mississippi lime zone. It is probable that additional gas production could be developed here. The deep wells show the Bartlesville sand to be absent. Ordovician rocks are as yet untested for oil on the crests of the domes, although several wells have tested Ordovician rocks on the flanks of the domes.

\section{COTTONMOUTH ANTICLINE}

The Cottonmouth anticline is one of the most prominent folds in central Osage County. It trends northeastward through the northcentral part of T. 24 N., R. 9 E., into the south-central part of T. 25 N., R. 9 E. The anticlinal structure of the exposed rocks is similar in general to that of the buried rocks except that the dips in the exposed rocks are much less steep. Furthermore, the exposed rocks are cut by several normal faults that trend northwestward and lie in a narrow northeastward-trending belt. The data are insufficient to determine whether the faults also displace the deeply buried rocks, but the few data available suggest that the faults terminate at shallow depth.

Thirty-seven wells have been drilled in secs. 3, 4, 9, and 10 on the Cottonmouth anticline Of these, 13 produced oil from the Peru sand at about 1,600 feet, 5 produced oil and 4 produced gas from the Oswego lime at about 1,700 feet, 2 produced gas from the Bartlesville sand at 1,950 feet, 1 produced oil and 1 produced gas from the Burgess sand-Mississippi lime zone at depths of 1,950 and 2,100 feet. The Peru sand oil wells produced initially from 20 to 2,400 barrels a day; the average initial daily yield was about 340 barrels. The Peru sand in the producing area ranges from 15 to 45 feet in thickness and is not present in most parts of Osage County outside of this field. It is probable that if additional wells were drilled the Peru sand would be found oil-bearing in part of the SW $1 / 4$ sec. 3. On the other hand the logs of the wells in the $\mathrm{SE} 1 / 4$ sec. 4 , the NE $1 / 4$ sec. 9, and the NW $1 / 4$ sec. 10 record no shows of oil in the Peru sand, indicating that the oil-bearing area in the SW $1 / 4$ sec. 3.may not be large.

The initial yields of the wells that produced oil from the Oswego lime ranged from 10 to 100 barrels, and such yields of those that produced gas ranged from $3,000,000$ to $9,000,000$ cubic feet. The Bartlesville sand is relatively thin or absent over most of the Cottonmouth anticline, and only two commercial gas wells were obtained in this sand; one well in the NW1/4 sec. 10 yielded initially $17,000,000$ cubic feet, and the other well near the center of the north line of the $\mathrm{NE} 1 / 4$ sec. 9 yielded gas at an undetermined rate. It is possible that additional gas or oil may be obtained on the anticline in the Bartles- 
ville sand, but the erratic occurrence of the sand in this area makes prospecting hazardous.

It is probable that additional oil and gas can be obtained in the Oswego lime in the $\mathbf{W} 1 / 2$ sec. 3 , and possibly elsewhere on the anticline. Furthermore, the yields of the wells producing from the Oswego lime probably can be increased materially by acid treatment of the reservoir rocks. One well in the southeast corner of the NW\%/4 sec. 3 had a recorded initial production of 25 barrels of oil a day from the Wayside sand. The log of only one other well on the Cottonmouth anticline records sand at the horizon of the Wayside sand. Therefore, it is improbable that additional wells can be expected in this sand.

Well 13 in the northwest corner of sec. 3 produced initially 75 barrels a day from the Burgess sand-Mississippi lime zone. The driller's $\log$ of this well indicates that no Burgess sand is present and that the oil occurs in the uppermost beds of the Mississippi lime. Well 1 in the northeast corner of sec. 9, on the crest of the anticline, yielded $9,000,000$ cubic feet of gas a day from the Burgess sandMississippi lime zone. Although several wells have penetrated the Burgess sand-Mississippi lime zone and failed to find oil, a few additional wells should be deepened into these beds before they are abandoned. The Siliceous lime has been tested by well 4 , in the southwest corner of sec. 3 on the crest of the anticline, and by several wells low on the flanks.

In the NW1/4 sec. 3, where all of the present producing oil wells are located, oil was first produced in May 1919. A total of 620,333 barrels had been produced by December 31, 1937, according to records of the Osage Indian Agency.

SEC. 1

The western flank of the Cochahee dome of Tps. 24 and $25 \mathrm{~N}$., R. 10 E., and the southern tip of the Saucy Calf anticline of T. 25 N., R. 9 E., extend into sec. 1, T. 24 N., R. 9 E. Several wells on these structural features, which lie in the Pershing oil and gas field, produce oil from the Bartlesville sand. The oil occurs in the lower part of the sand; the upper part, known to the drillers as gas sand, is barren in some wells and yields gas in others. The initial daily yields of the wells ranged from 5 to 400 barrels. The wells were drilled from 1918 to 1920 , and most of them are still producing oil. The boundary of the producing area in sec. 1 appears to have been established by several dry holes.

In the NE1/4 sec. 1, oil was first produced in May 1918, and a total of 263,811 barrels had been produced by December 31, 1934. In the NW $1 / 4$ sec. 1 oil was first produced in January 1920, and a total of 74,956 barrels had been produced by December 31, 1934. 


\section{T. 25 N., R. 9 E.}

T. 25 N., R. 9 E., is in central Osage County and contains Pawhuska, the county seat. The township lies on the northwest margin of a region that includes many oil and gas fields, and more than 400 wells have been drilled in the township. Oil or gas has been produced in commercial amounts in 10 localities and from 6 beds, all of which lie at depths of considerably less than 2,500 feet. The Bartlesville sand, which is the most prolific oil- and gas-producing bed in northeastern Oklahoma, is the main producing sand in the southeastern part of T. $25 \mathrm{~N}$., R. 9 E. This sand is absent in most of the township, except the southeastern third, but the western part of the township lies in a belt of country that contains many oil pools in the Burgess sand-Mississippi lime zone. The Squirrel sand is the main gas-producing bed in the north-central part of the township and is the main source of the gas used in Pawhuska. It is noteworthy that Ordovician rocks, which yield large amounts of oil in many localities in southern Osage County, produce no oil or gas in T. 25 N., R. 9 E. A few localities in the township have value as prospective testing sites for additional oil and gas.

Development of the oil and gas resources of T. 25 N., R. 9 E., began early. A few gas wells in sec. 3 were drilled from 1903 to 1906 ; many other wells in the north-central part of the township were drilled from 1913 to 1920 . Most of the wells in that part of the Pershing field that lies in secs. 23 to 25,35 , and 36 of this township were drilled from 1919 to 1923 , although several wells were drilled near the common corner of secs. $25,26,35$, and 36 from 1914 to $1917 .^{39}$ The wells in the $W 1 / 2$ sec. 26 were drilled from 1927 to 1929; those in the large field in the south-central part of the township were drilled from 1919 to 1922. The wells on the Mayer anticline in sec. 19 were drilled from 1919 to 1924 , and the wells on the Ducotey dome in sec. 17 were drilled from 1920 to 1926.

The subsurface investigation of T. 25 N., R. 9 E., was made in 1935 mainly by N. W. Bass.

\section{STRUCTURE AND DEVELOPMENT}

T. 25 N., R. 9 E., lies near the northeast end of a belt of sharply folded domes, anticlines, and structural basins that extends from west-central Creek County northeastward through south-central Osage County. These structural features are superposed on a regional monocline whose rocks dip westward at an average rate through central Osage County of 33 feet to the mile. The exposed rocks in T. 25 N., R. 9 E., are cut by several normal faults that are a mile or

\footnotetext{
${ }^{39}$ Rubey, W. W., Progress report on a subsurface study of the Pershing oil and gas field, Osage County,
} Okla.: U. S. Geol. Survey Bull. 751, p. 26, 1925. 
less in length and trend northwestward. The exposed beds are displaced vertically less than 50 feet along the faults. ${ }^{40}$ The investigation of the subsurface structural features did not determine whether the deeply buried rocks are cut by the faults (pl. 3). Most of the structural features of the deeply buried rocks are present in the exposed rocks. However, the variation between the subsurface structure (as expressed on $\mathrm{pl} .3$ ) and the structure of the exposed rocks in $\mathrm{T}$. $25 \mathrm{~N} .$, R. 9 E., is greater than in much of Osage County. As elsewhere in northern Oklahoma, the buried rocks are more steeply folded than the exposed rocks, and the crests of the folds in the buried rocks are not directly beneath the crests in the exposed rocks. The crests of several of the domes on the Oswego lime (pl. 3) lie about a quarter of a mile southwest and others a similar distance northwest of the crests on the exposed rocks. Oil or gas has been produced from most of the domes, but the amount has been exceedingly small on several of the most promising domes.

\section{SAUCY CALF ANTICLINE AND PERSHING FIELD}

The northern part of the large Pershing field occupies a belt of country a little more than a mile wide and 3 miles long in the southeasternmost part of the township. The oil field lies on a large anticline ${ }^{41}$ that trends northwestward through the northwestern part of T. 24 N., R. 10 E., the southwesternmost part of T. 25 N., R. 10 E., and the southeastern part of T. 25 N., R. 9 E. Several subsidiary domes, anticlines, and synclines are superposed on the major anticline; one of these is the Saucy Calf anticline, whose crest trends northeastward through parts of secs. 35, 36, 25, and 24 (pl. 3). Others are the North Cochahee and South Cochahee domes, whose crests lie outside the boundaries of T. 25 N., R. 9 E. ${ }^{42}$ A part of the west flank of the North Cochahee dome extends into the E $1 / 2$ sec. 36 .

The oil and gas of the Pershing field are produced from the Bartlesville sand at a depth of about 2,000 feet. Many wells found shows of oil or gas in the Oswego lime, and several wells had shows of oil or gas in the Hogshooter limestone. Oil was discovered in the Pershing field in 1914, but only a few wells were drilled prior to 1919. The field was developed rapidly from 1920 to 1923 , and most of the wells are still producing. The initial production of the oil wells ranged from 15 to 1,500 barrels. Eighteen wells had initial yields of 500 or more barrels. A few wells that are on the crests of local

\footnotetext{
${ }^{10}$ Heald, K. C., in White, David, and others, Structure and oil and gas resources of the Osage Reservation, Okla.: U. S. Geol. Survey Bul. 686, pl. 7, 1922.

${ }^{11}$ Rubey, W. W., Progress report on a subsurface study of the Pershing oll and gas field, Osage County, Okla.: U. S. Geol. Survey Bull. 751, pl. 8, 1925. Bass, N. W., Kennedy, L. E., Dillard, W. R., and Leatherock, Constance, Subsurface geology of Osage County, Okla.: United States Department of the Interior Press memorandum 105368, pl. 1, 1936.

2 Heald, K. C., op. cit., pl. 7. Rubey, W. W., op. cit., pl. 8.
} 
domes produced gas instead of oil. The producing area conforms more closely with the area of the major anticline than is common for Bartlesville sand oil fields in Osage County.

The producing area of the Pershing oil field appears not to have been completely drilled. For example, the producing parts of secs. 24,25 , and 36 doubtless could have been extended by the drilling of additional wells at the time, or shortly after the time, of the main development of the field. Some parts of these sections may yet contain sufficient oil in the Bartlesville sand to warrant the drilling of additional wells. The fact that wells whose initial yields were from 400 to 1,000 barrels a day are offset by wells whose initial yields were from 15 to 50 barrels suggests that the variations in the character of the reservoir sand are abrupt. Therefore, it is not improbable that there are local areas in the field that have been drained but little by the nearby producing wells.

The deep syncline that lies between the Saucy Calf anticline on the east and the Cottonmouth and Wooster anticlines on the west and southwest is interrupted in the $W 1 / 2$ sec. 26 by a small dome. The dome has a structural closure of less than 20 feet, and the Oswego lime on its crest is 40 feet lower than on the crests of the neighboring anticlines. Nevertheless 19 wells (including well 454) on the dome yielded oil from the Bartlesville sand. The initial yields of the wells ranged from 25 to 1,800 barrels, and 9 of the wells yielded more than 100 barrels a day. Most of the wells have been producing 9 to 10 years. Gas was found in the upper part of the Bartlesville sand and oil in the lower part. The drillers' logs and a microscopic examination of samples from one well indicate that the sand lies in contact with chert of the Mississippi lime in some wells and is separated from the lime by a thin shale bed in other wells. It appears probable that the oil may occur in the lowermost part of the Bartlesville sand and the uppermost part of the Mississippi lime. If so, this fact may reasonably account for the large variations in initial yields of the wells because the Mississippi lime commonly supplies producers. with a wide range in initial volumes. Well 454 in the $\mathrm{NE}_{1 / 4} \mathrm{NW}_{1 / 4} \mathrm{SW} 1 / 4$ sec. 26, an old oil well producing from the Bartlesville sand, was plugged back recently to the Oswego lime, where it was treated with acid and converted into a gas well that produces some oil. The initial daily yield of the gas was $1,210,000$ cubic feet. Well 7A in the SW1/4 NE1/4 sec. 26 had at the time of drilling 200 feet of oil in the hole from the Bartlesville sand, suggesting that a larger part of the NE $1 / 4$ sec. 26 than that occupied by producers 5 and 6 contains oil in the Bartlesville sand. 


\section{WOOSTER ANTICLNNE AND NORTH PART OF COTTONMOUTH ANTICRNE}

The Wooster anticline trends northeastward through secs. 32,33 , 28 , and 27; and the northern part of the Cottonmouth anticline, which lies mainly in T. 24 N., R. 9 E., trends northward through secs. 34 and 27. Apparently the two anticlines coalesce in the dome in the SW1/4 sec. 27. Both anticlines contain subsidiary domes distributed along their crests. Both anticlines have proved disappointing as sites for large oil fields, but considerable oil has been found in the Bartlesville sand on the west flank of the Cottonmouth anticline and the southeast flank of the Wooster anticline and in the syncline between the two anticlines. Gas has been produced from the Bartlesville sand in a few wells on the higher parts of the anticlines. The occurrence of oil and gas in the Bartlesville sand appears to bear little relation to the main structural features of the rocks, except that the gas and oil are segregated.

The oil in the Bartlesville sand occurs in the lower part of a thick body of sand that lies on chert beds of the Mississippi lime. Microscopic examination of samples from a few wells showed that the uppermost 5 to 10 feet of the chert-bearing beds had been penetrated by the drill. It is not improbable, therefore, that in some wells the oil is produced from both the Bartlesville sand and the Mississippi lime, and it is possible that the Mississippi lime is the sole producer in some wells. The abandoned Bartlesville sand producers in the northwest corner of the $\mathrm{SE} 1 / 4 \mathrm{sec}$. 34, the $\mathrm{NE} 1 / 4 \mathrm{sec}$. 34, and the $\mathrm{SE} 1 / 4 \mathrm{SE} 1 / 4$ sec. 27 yielded initially 25 barrels or more, indicating that oil would be found in the Bartlesville sand in that part of sec. 34 that lies between these abandoned wells and the main oil pool in the westernmost part of sec. 34. Wells with small initial yields should be expected, however.

The Oswego lime produced oil in several wells and gas in one well in this field, and the Big lime yielded oil in four wells. Three wells near the crest of the sharply folded dome in the $\mathrm{NE}_{1 / 4}^{1 / 4} \mathrm{sec} .32$ yielded oil for a time from the Bartlesville sand. In southern Osage County, domes similar to those in secs. $32,28,27$, and 34 commonly yield large volumes of oil from the Siliceous lime, but this lime has been tested here and found barren.

\section{OKAY ANTICLINE}

The Okay anticline in secs. 31 and 30 is a sharp fold with a structural closure of nearly 100 feet on the top of the Oswego lime. The crest. of the anticline on the Oswego lime (pl. 3) lies nearly a quarter of a mile northwest of the crest on the exposed rocks. ${ }^{43}$ The anticline has proved disappointing as an oil field. Gas is produced from the Burgess sand-Mississippi lime zone in one well and from the Oswego

\footnotetext{
13 Heald, K. C., in White, David, and others, Structure and oil and gas resources of the Osage Reservation, Okla.: U. S. Geol. Survey Bull. 686, pl. 7, 1922.
} 
lime in one well. The initial yield of the well producing from the Burgess sand-Mississippi lime zone was $3,000,000$ cubic feet and that of the well producing from the Oswego lime was 5,000,000 cubic feet. Each of these wells had shows of gas in the Big lime and in sands near the middle of the Nelagoney formation that were encountered at depths of 700 to 800 feet. The dry hole in the NW $1 / 4$ sec. 31 , on the crest of the dome, tested the upper part of the Siliceous lime but found no oil or gas. Of the seven wells drilled on the Okay anticline, five reached the Mississippi lime, one reached the upper part of the Cherokee shale, and one penetrated the Oswego lime. It is probable that additional gas wells could be obtained on the anticline.

\section{MAYER ANTICLINE}

The eastern part of the Mayer anticline occupies parts of secs. 19 and 30. It appears probable, however, that the main fold in secs. 30 and 19 represents a northern projection of the Okay anticline and its junction in sec. 19 with the Mayer anticline. The position of the highest contout in secs. 30 and 19, as shown on plate 3 , is somewhat speculative because the authors' data showing the elevations of the well mouths in sec. 19 contained several inaccuracies.

All oil produced in secs. 19 and 30 is derived from the Burgess sand-Mississippi lime zone at depths of about 2,250 feet. The oilbearing bed is reported in the logs as sand, chert, or lime. Microscopic examination of samples from several wells in the field shows that the oil-bearing bed is composed of chert and occupies the top few feet of the Mississippi lime. The initial yields of the wells ranged from 5 to 125 barrels of oil a day, and most of the wells yielded from 25 to 100 barrels.

None of the logs reported finding the Bartlesville sand; one well had a show of oil and gas in a thin sand found near the middle of the Cherokee shale a short distance above the position of the Bartlesville sand. The Squirrel sand, in the upper part of the Cherokee shale, is present in all wells except those in the extreme southeastern and southern parts of the field. The Squirrel sand supplied a show of oil in two wells and water in all others. One well had a show of oil and gas in the Oswego lime. The Peru sand, from 25 to 50 feet thick, is present in all wells except three and furnished shows of oil in six wells. Four wells had shows of oil in the Big lime. Four wells in the SW1/4 sec. 19 had shows of gas at a depth of about 800 feet in sand that lies in the Okesa, Torpedo, and Clem Creek sand zone. Well 2 in the NW $1 / 4$ sec. 19 and well 1 in the northwest corner of sec. 30 tested the Siliceous lime but found it barren of oil or gas. It appears probable that the producing area could be extended in secs. 19 and 30 by drilling additional wells to the oil-bearing bed near the top of the Mississippi lime. However, most wells in the field produce much 
water. Therefore the performance of the individual wells should be investigated before more wells are drilled. If additional wells are drilled the possibility of developing the oil shows in the Big lime and those in the Oswego lime into commercially valuable yields by treatment of the beds with acid should be considered.

\section{DUCOTEY DOME}

The Ducotey dome, whose crest is in the $\mathrm{E} / 2$ sec. 17, appears to have a little more than 40 feet of structural closure on the top of the Oswego lime and may have more; the amount is uncertain because the data available are insufficient to show the depth of the syncline that lies in sec. 16 and separates the Ducotey dome from the south dome of the Pawhuska anticline. The crest of the Ducotey dome on the Oswego lime lies a little more than a quarter of a mile northwest of its position on the exposed rocks. ${ }^{44}$ Furthermore, the exposed rocks are cut by two faults which trend northwest, one through the $\mathrm{W} \frac{1}{2}$ sec. 16 and the other through the $\mathrm{SE} / 4$ sec. 17 . The exposed rocks are displaced vertically from 20 to 25 feet along the faults. The data are insufficient to determine whether the deeply buried rocks also are displaced.

All of the oil and some of the gas produced from the Ducotey dome is found in the Squirrel sand at depths of about 1,900 feet. Wells on the flanks of the dome yield water in the Squirrel sand. Most of the oil wells produced gas from the upper part of the Squirrel sand and oil from the lower part. The initial daily yields of the oil wells ranged from 25 to 200 barrels, and the initial daily yield of the gas. well (No. 5) in the $\mathrm{SE} 1 / 4$ sec. 17 was $11,000,000$ cubic feet. The Squirrel sand varies abruptly in thickness; it has a maximum thickness of about 100 feet but is only 50 feet thick in most wells on the dome. The sand is absent a short distance east of the dome, according to the well logs.

The Big lime, which lies about 200 feet above the Squirrel sand, produced gas in five wells near the crest of the Ducotey dome and produced shows of gas in five other wells near the gas wells.

The city of Pawhuska well 8 , in the center of the NE1/4 $\mathrm{SE}_{1 / 4}$ sec. 17, produced initially 500,000 cubic feet of gas a day from the Layton sand at a depth of 1,210 feet. Four other wells found shows of gas in this sand. Well 1 in the $\mathrm{SE} 1 / 4$ sec. 17 was drilled through the Oswego lime, was plugged back, and yielded 750,000 cubic feet of gas from the Big lime. Six wells had shows of oil or gas, and one well produced 250,000 cubic feet a day for a time from the upper part of the Oswego. lime. The dome lies in a belt of country that contains many oil pools in the Burgess sand-Mississippi lime zone, and 10 wells on the flanks of the dome reached the Mississippi lime. The logs of only two

" Heald, K. C., op cit., pl. 7. 
of these wells record shows of oil in the lime. Well 2 in the SW1/4 NW1/4$\mathrm{SW} 1 / 4$ sec. 16 penetrated a thin sand at a depth of 2,580 feet, immediately below the Mississippi lime, which yielded a hole full of water. The sand may belong in the Simpson formation but more likely represents the top bed in the Siliceous lime. This well should not be regarded as an adequate test of the oil possibilities of the Siliceous lime because it is not on the crest of the dome. Therefore one of the wells in the SE1/4 sec. 17, on the crest of the dome, should be deepened into the Siliceous lime before it is abandoned. Some additional gas production might be developed by acid treatment of the Oswego lime and the Big lime.

\section{PAWHUSKA ANTTCLINE}

The Pawhuska anticline trends slightly west of north through secs. 15, 10, and 3. Two somewhat broad domes are superposed on its crest, and two prominent anticlinal noses trend southeastward from its east flank. The nose in sec. 11 and the eastward-trending anticline in sec. 12 appear to represent the subsurface expression of the Prue anticline shown by Heald ${ }^{45}$ in secs. 11 and 12 .

Gas is produced from the Squirrel sand on the northern part of the Pawhuska anticline, and oil is produced from rocks that lie about 50 feet below the top of the Mississippi lime in a small area in secs. 10 and 11 on the southern part of the anticline. The initial daily yields of the gas wells ranged from 500,000 to $22,000,000$ cubic feet, and such yields of the oil wells ranged from 5 to 25 barrels. The gasbearing Squirrel sand, which lies at a depth of about 1,700 feet, ranges from a feather edge to 100 feet in thickness and is about 40 feet thick where it is gas bearing. The well logs indicate that the Squirrel sand occupies a belt that extends from secs. 2 and 3 southwestward to sec. 19. The wells near the center of sec. 10 , in the $S \frac{1}{2}$ sec. 10 , and in secs. 11 and 15 on the southern part of the Pawhuska anticline lie southeast of the belt containing the Squirrel sand. In this area shale occupies the position of the Squirrel sand.

Many wells on the Pawhuska anticline had shows of oil and gas in the Layton sand, the Big lime, and the Oswego lime, and several wells had shows in the Peru sand. Many sands in the Nelagoney and Ochelata formations that produce oil and gas in several localities in south-central Osage County yield only water on the Pawhuska anticline.

Ordovician rocks have not been tested on the crest of the anticline. Nevertheless, three wells on the flanks of the anticline reached the uppermost part of the Siliceous lime; of these, only one well found shows of oil or gas. Well 1 in the southeast corner of the NW1/4 sec. 10 is reported to have yielded gas at the rate of $4,500,000$ cubic feet a

\footnotetext{
45 Heald, K. C., in White, David, and others, Structure and oil and gas resources of the Osage Reservation, Okla.: U. S. Geol. Survey Bull. 686, pl. 7, 1922.
} 
day from sand that is 6 feet thick and forms the top bed of the Ordovician sequence. The well yielded a hole full of water when drilled 2 feet deeper than the gas sand.

\section{OTHER DOMES AND ANTICLINES}

Five wells, three of which produced oil or gas for a time, were drilled on a small dome near.the center of sec. 14 . One well produced initially 50 barrels of oil a day from the Oswego lime, and another well produced initially 4,000,000 cubic feet of gas a day from the Bartlesville sand but ceased producing after yielding a total of about $80,000,000$ cubic feet.

The Prue anticline in secs: 11 and 12 has been tested by three wells that reached the Mississippi lime. The crest of the anticline is 60 feet or more lower than the crest of the Pawhuska anticline. It lies east of the belt of country that contains the Squirrel sand and near the northwest margin of the region that contains the Bartlesville sand. The logs of all wells in sec. 11 and of the well in the SW $1 / 4 \mathrm{NW} 1 / 4$ sec. 12 record no Bartlesville sand, but the logs of all wells in sec. 13 and several wells in sec. 14 record the presence of this sand. In view of these facts the Prue anticline does not appear to be particularly attractive for prospecting for oil and gas, but the possibility of finding. oil and gas in the Bartlesville sand and the Burgess sand-Mississippi lime zone has not been entirely disproved. The relatively broad structural nose in the $\mathrm{NW} 1 / 4$ sec. 13 has about the same prospective value as the Prue anticline.

The positions of the structure contours drawn on plate 3 in secs. 5 and 6, showing the Gibson domes, are based almost entirely on Heald's ${ }^{46}$ structure contour map of the exposed rocks. Two wells here reached the Mississippi lime, and one of the wells probably penetrated the uppermost few feet of the Ordovician rocks, according to the log.

\footnotetext{
10 Heald, K. C., op. cit., pl. 7.
} 